\title{
Energetic and exergetic analysis of a domestic refrigerator system with LPG as a replacement for R134a refrigerant, using POE lubricant and mineral oil based $\mathrm{TiO}_{2}-, \mathrm{SiO}_{2}$ - and $\mathrm{Al}_{2} \mathrm{O}_{3}$-lubricants
}

\author{
Jatinder Gill ${ }^{\mathrm{a}, *}$, Jagdev Singh ${ }^{\mathrm{b}}$, Olayinka S. Ohunakin ${ }^{\mathrm{c}, \mathrm{d}}$, Damola S. Adelekan ${ }^{\mathrm{c}}$ \\ ${ }^{a}$ Director of Aman Bhalla Institute of Engineering and Technology, Pathankot, Punjab, India \\ ${ }^{\mathrm{b}}$ Faculty of Mechanical Engineering Department, BCET Gurdaspur, Punjab, India \\ ${ }^{\mathrm{c}}$ The Energy and Environment Research Group (TEERG), Mechanical Engineering Department, Covenant University, Ogun State, Nigeria \\ d University of California, Berkeley, USA
}

\section{A R T I C L E I N F O}

\section{Article history:}

Received 5 December 2017

Revised 8 May 2018

Accepted 12 May 2018

Available online 17 May 2018

\section{Keywords:}

LPG

Nanoparticles

COP

Total irreversibility

Second law efficiency

Domestic refrigerator

\begin{abstract}
A B S T R A C T
This paper experimentally investigated energetic and exergetic performance analysis of a domestic refrigerator using R134a and LPG refrigerants with different lubricants (polyol-ester (POE), mineral oil (MO), and $\mathrm{TiO}_{2}, \mathrm{SiO}_{2}, \mathrm{Al}_{2} \mathrm{O}_{3}$ nanoparticles dispersed in mineral oil).The energetic and exergetic performance analysis of the domestic refrigerator were investigated with test parameters including compressor power consumption, cooling capacity, coefficient of performance (COP), discharge temperature, irreversibility in the components, total irreversibility and second law efficiency. Findings showed that the lowest compressor power consumption and total irreversibility were observed in refrigerator with $40 \mathrm{~g}$ charge of $\mathrm{LPG} / \mathrm{TiO}_{2}$-MO lubricant $\left(0.2 \mathrm{~g} / \mathrm{L}\right.$ of $\left.\mathrm{TiO}_{2}\right)$; these values of compressor power consumption and total irreversibility were $15.87 \%$ and $31.69 \%$, respectively, lower than for $\mathrm{R} 134 \mathrm{a} / \mathrm{POE}$ lubricant. In addition, the domestic refrigerator using LPG refrigerant at $40 \mathrm{~g}$ charge with $\mathrm{TiO}_{2}-\mathrm{MO}\left(0.2 \mathrm{~g} / \mathrm{L} \mathrm{TiO}_{2}\right)$ lubricant, had the highest $\mathrm{COP}$ and second law efficiency among the selected nano-lubricants. These values of COP and second law efficiency were $56.32 \%$ and $47.06 \%$, respectively, higher than that of R134a/POE. Futhermore, compressor discharge temperature of the domestic refrigerator with $40 \mathrm{~g}$ charge of $\mathrm{LPG} / \mathrm{TiO}_{2}-\mathrm{MO}$ lubricant $\left(0.2 \mathrm{~g} / \mathrm{L}\right.$ of $\left.\mathrm{TiO}_{2}\right)$ was found to be lower than that of R134a/POE. Hence, extended compressor life may be expected with the adoption of $\mathrm{TiO}_{2}$-Mineral oil lubricant. It can be concluded that based on energetic and exergetic performance analysis, the domestic refrigerator using the $40 \mathrm{~g}$ charge of $\mathrm{LPG} / \mathrm{TiO}_{2}-\mathrm{MO}(0.2 \mathrm{~g} / \mathrm{L}$ $\mathrm{TiO}_{2}$ ) performed better than $\mathrm{R} 134 \mathrm{a} / \mathrm{POE}$.
\end{abstract}

(c) 2018 Elsevier Ltd and IIR. All rights reserved.

\section{Analyse énergétique et exergétique d'un réfrigérateur domestique fonctionnant avec du GPL en remplacement du R134a, utilisant du lubrifiant POE et des lubrifiants à base d'huiles minérales $\mathrm{TiO}_{2}, \mathrm{SiO}_{2}$ et $\mathrm{Al}_{2} \mathrm{O}_{3}$.}

\section{Introduction}

Energy and exergy performance analyses can be used to increase utilization proficiency of energy resources of various ther-

\footnotetext{
* Corresponding author.

E-mail address: gillzy1985@gmail.com (J. Gill).
}

modynamic systems. Besides, substantial advancements has been witnessed in numerous applications that employed these analyses recently. Because energy analysis is based on the First Law of Thermodynamics which does not consider change in quality of energy, the influence of process environment and irreversibility during the processes in systems, it makes conventional thermodynamic examination techniques rather inadequate. To conquer this inadequacy, 


\begin{tabular}{|c|c|}
\hline \multicolumn{2}{|c|}{ Nomenclature } \\
\hline e & specific exergy, $\mathrm{kJ} \mathrm{kg}^{-1}$ \\
\hline S & entropy, $\mathrm{kJ} \mathrm{kg}^{-1} \mathrm{~K}^{-1}$ \\
\hline $\mathrm{T}$ & temperature $\mathrm{K}$ \\
\hline I & irreversibility, kW \\
\hline GWP & global warming potential \\
\hline $\mathrm{P}$ & pressure, Bar \\
\hline h & enthalpy, $\mathrm{kJ} \mathrm{kg}^{-1}$ \\
\hline W & compressor power $\mathrm{kW}$ \\
\hline Q & cooling capacity, kW \\
\hline MO & mineral oil \\
\hline POE & polyol ester oil \\
\hline LPG & liquefied petroleum gas \\
\hline $\mathrm{U}_{\mathrm{R}}$ & total uncertainty \\
\hline $\mathrm{U}_{\mathrm{V}_{\mathrm{i}}}$ & uncertainty of each independent variable \\
\hline $\mathrm{E}^{\cdot}$ & total exergies, $\mathrm{W}$ \\
\hline \multicolumn{2}{|c|}{ Greek Letters } \\
\hline$\xi$ & mass flow rate, $\mathrm{kg} \mathrm{s}^{-1}$ \\
\hline$\mu$ & dynamic viscosity, Pa s \\
\hline$\rho$ & density, $\mathrm{kg} \mathrm{m}^{-3}$ \\
\hline$\eta$ & second law efficiency (\%) \\
\hline \multicolumn{2}{|c|}{ Subscripts } \\
\hline evap & evaporator \\
\hline Cap & capillary \\
\hline Comp & compressor \\
\hline Cond & condenser \\
\hline in & inlet \\
\hline Out & outlet \\
\hline b & boundary \\
\hline 0 & dead state \\
\hline f & fluid \\
\hline & total \\
\hline d & discharge \\
\hline
\end{tabular}

the idea of exergy rapidly became a critical technique in recent years. Exergy is characterized as the available useful work obtained in a system, when brought to dead state or standard ambient conditions (Rosen et al., 2008; Dincer and Rosen, 2005). No exergy lost is assumed in an ideal energy transformation process, yet in actual practice, the exergy loss (irreversibility) occurs, and it constitutes the fundamental contrast amongst energy and exergy. Hence, exergy analysis is a more acceptable measure of environmental and economic performance of a process than energy analysis. Since exergy investigation measures location, types, and magnitude of exergy loss in a system, its analysis can be used to enhance the effectiveness of such systems (Bejan, 2002); exergy analysis can also be used to determine subsystems performances (Fang et al., 2005), and can discover the part having the most and the least exergy loss within a system. In exergy analysis, the principles of conservation of energy and mass and the second law of thermodynamics are used to reveal improvement potential of subsystems, and the overall performance of the system. Due to the continuous thermodynamic phase change processes in refrigeration systems, energy analysis alone is not sufficient, but also requires exergy analysis (Hepbasli, 2007). Various researchers had considered the theoretical and experimental exergy analysis of refrigeration system (see Arora and Kaushik, 2008; Kabul et al., 2008; Ahamed et al., 2010; 2011; Saravanakumar and Selladurai, 2014 Raveendran and Sekhar, 2017; Golzari et al., 2017 and Gill and Singh, 2017a). These literatures alluded in this paper, emphasizes that exergetic analysis and its derivatives give significant data over the corresponding energy analysis, and thus proposed potential areas for performance improvement in a refrigeration system. According to the Kyoto Protocol, hydrofluorocarbon (HFC) refrigerants including R134a must be discontinued, but many developing nations still made heavy use R134a refrigerants (an HFC compound) in refrigeration devices, because their utilization have shown excellent thermodynamic and thermophysical properties, thus bringing about reduced cost implications. However, securing a refrigeration system against leakage of R134a (HFC) refrigerant is impractical and for all intents, leakages of HFC refrigerants will contribute to global warming (Sanchez et al., 2017), knowing fully well that R134a refrigerant has a high global warming potential (GWP) of 1430 (Gill and Singh, 2017a; 2017b). Due to the attendant issue of global warming with HFC refrigerants, instant prohibition of R134a is very essential for environmental safety. Apart from the attendant high GWP of R134a, the refrigerant also has inherent side effect such as immiscibility with mineral oils (Gill and Singh, 2017a; 2017b). Though R134a is compatilible with Polyol ester oil (POE) compressor lubricants, they are readily hygroscopic in nature (see Gill and Singh, 2017b; 2017c). These hygroscopic nature of POE lubricant increases affinity for moisture build-up, thereby increasing frequency of maintenance of compressors (Gill and Singh, 2017d; 2017e). Therefore, in a bid to meet global convention objectives, the need for a suitable long-term alternative refrigerants as suitable replacement to R134a refrigerant is very essential (Mohanraj et al., 2011). One suitable replacement for R134a is Liquefied Petroleum Gas (LPG). Though different blends of LPG as refrigerants have flammability issues, they are still being safely utilized in refrigeration systems provided they are charged with limit of not more than $150 \mathrm{~g}$. They have advantages of low cost, readily available in bulk quantity especially in oil producing regions, zero Ozone depletion potential (ODP), and very low GWP (Mohamed, 2015). Several researchers have reported LPG refrigerant as bringing about significant improvement to energy efficiency of refrigeration systems, and also an environmentally friendly alternative to R12 and R134a refrigerants, with or without the modification of existing refrigeration system. In a related work, Akash and Said (2003) reported that LPG (composed of R290, R600, and R600a, in the ratio of 30:55:15, by mass) gave better energy performance when compared to R12. Furthermore, Fatouh and Kafafy (2006), Ahamed et al. (2012), Srinivas et al. (2014), Babarinde et al. (2015) and Adelekan et al. (2017), also reported that LPG gave similar better energy performances in domestic refrigerator systems, when compared to R134a.

Furthermore, a new concept whereby nanoparticles are added as additives into refrigerants to obtain a homogenous mixture often referred to as "nano refrigerant" is gradually gaining wide recognition. Refrigerants are working fluids used in heat transfer cycles undergoing continous phase change due to excessive rate of heat transfer reactions. Although, most of the fluids can find themselves a place in refrigeration cycles, only fluorocarbons or chlorofluorocarbons are considered ideal refrigerant according to general opinion. One-step and two-step methods are used to readily synthesize nano-refrigerants; but between these two methods, two-step is widely adopted for preparing nano-refrigerants due to the simplicity of its technique. In this method, the nano-materials (previously synthesized as dry powders, using thermal decomposition or photochemical methods, or transition metal salt reduction, or ligand reduction and displacement from organo-metallics, or metal vapor synthesis, and electrochemical synthesis methods (see Botha, 2007) having nano size between 1-100 nm, are added to compressor oil to form nanoparticle/oil mixture. This mixture is dispersed by using any suitable dispersion techniques such as ultrasonic agitation, magnetic force agitation, homogenizing, high-shear mixing (Yu and Xie, 2012). In one-step method, vapor phase of nano-powders are condensed into a liquid hav- 
ing low vapor pressure, and dissolved in the liquid at the same time. The nanoparticles are produced by applying a physical vapor deposition method, or liquid chemical method (Sundar et al., 2013). Several researchers in previous work, have used nanoparticles for energetic and exergetic performance improvement of refrigeration systems (see Wang et al., 2003; Bi et al., 2008; Jwo et al., 2009; Bobbo et al., 2010; Subramani and Prakash, 2011; Padmanabhan and Palanisamy, 2012; Sabareesh et al., 2012; Kumar and Elansezhian, 2012; Lou et al., 2015; Azmi et al., 2016; Azmia et al. 2017; Ohunakin et al., 2017, and so on).

In addition, the adoption of LPG as a refrigerant in refrigeration systems, with or without the need for slight modification of the system, was recently reported to have brought about high energy efficiency of the system, thus justifying their appropriateness as a suitable alternative (Adelekan et al., 2017; Ohunakin et al., 2017). In Ohunakin et al. (2017), the energetic performance of a domestic refrigerator system with nanoparticle-lubricant mixture and LPG refrigerant was reported. It was found in the work that the application of $\mathrm{TiO}_{2}$ and $\mathrm{SiO}_{2}$ nanoparticles in the refrigeration systems, improved the energetic performance of the system; $\mathrm{Al}_{2} \mathrm{O}_{3}$-lubricant was found to be incompatible with LPG refrigerant because of the attendant high power consumption of the refrigeration system with the use of the nano-lubricant. It should also be noted in Ohunakin et al. (2017), that exergetic performance analysis of the domestic refrigerator system using LPG refrigerant (working fluid) and nanoparticle-lubricant mixtures, and the comparison of same with R134a refrigerant was not examined. However, in this work, the energetic and exergetic performance analysis of a domestic refrigerator system containing nanoparticle-lubricant mixtures and LPG refrigerant was carried out, to extend the current frontier of knowledge. The compressor power consumption, cooling capacity, coefficient of performance (COP), discharge temperature, irreversibility in the components of the refrigerator, total irreversibility, and the second law efficiency of the refrigerator system, were the parameters of the energetic and exergetic performance analysis, selected in this research work. The parameters of the energetic and exergetic performance analysis obtained with the nanoparticle-lubricant mixtures and LPG refrigerant, were compared with parameters obtained using R134a refrigerant with POE lubricant under similar operating conditions.

\subsection{Preparation of nanoparticle-lubricant mixtures}

The selected nanoparticles namely: $\mathrm{TiO}_{2}, \mathrm{Al}_{2} \mathrm{O}_{3}$, and $\mathrm{SiO}_{2}$, were added separately to the lubricant in the compressor unit of the system. The preparation and stability of the lubricant and nanoparticle mixtures are essential. The desirable properties of nanolubricants like stablility, durability suspension, less coagulation, and neutral chemical reaction were attained during nano-lubricant preparation. Capella mineral oil (MO) (ISO viscosity grade 68) was selected as a lubricant based on its compatibility with LPG refrigerant (Ohunakin et al. 2017). The selected nanoparticles $\left(\mathrm{TiO}_{2}\right.$, $\mathrm{Al}_{2} \mathrm{O}_{3}$, and $\mathrm{SiO}_{2}$ ) were procured from Alfa Aesar and Aldrich Chemistry laboratories (see Table 3 for details on nanoparticle). The nanoparticles were measured using digital weighing scale (OHAUS Pioneer TM PA114) with measurement range of 0.0001-110 g, and mixed with $1 \mathrm{~L}$ of Capella mineral oil in order to synthesize the nano-lubricants, as recommended for nanofluid preparation (Sendil and Elansezhain, 2012). Scanning Electron Microsopy (SEM micrograph) and EDX diffractogram of $\mathrm{Al}_{2} \mathrm{O}_{3}, \mathrm{TiO}_{2}$, and $\mathrm{SiO}_{2}$ nanoparticles are as shown in Figs. 1 and 2. In this work, two-step process of preparation of nano-lubricant was followed as justified in the work of Sendil and Elansezhain (2012). Samples $\mathrm{TiO}_{2}, \mathrm{Al}_{2} \mathrm{O}_{3}$, and $\mathrm{SiO}_{2}$ nanoparticles and mineral oil mixtures were separately prepared with the aid of a magnetic stirrer for ten (10) hours. The
Table 1

\begin{tabular}{lll}
\multicolumn{2}{l}{ Description of the refrigerator system. } \\
\hline S/N & Refrigerator description & Units \\
\hline 1 & Evaporator size & $62 \mathrm{~L}$ \\
2 & Power rating & $110 \mathrm{~W}$ \\
3 & Voltage rating & $220-240 \mathrm{~V}$ \\
4 & Refrigerant type & $\mathrm{R} 134 \mathrm{a}$ \\
5 & Mass charge & $100 \mathrm{~g}$ \\
6 & Compressor type & $\mathrm{HFC}\left(5.1 \mathrm{~cm}^{3} ; 2900 \mathrm{rpm}\right)$ \\
7 & Condenser type & Natural air cooled \\
8 & Capillary tube length & $2 \mathrm{~m}$ \\
9 & Capillary tube inner daimeter & $1.40 \mathrm{~mm}$ \\
10 & Evaporator size & $420 \times 970 \mathrm{~mm}$ \\
11 & Number of doors & Single \\
\hline
\end{tabular}

blend was constantly being kept vibrated with an ultrasonic homogenizer for $15 \mathrm{~h}$ to completely isolate the nanoparticles, and to prevent any of the particles in the blend from acquiring legitimate homogenization. Proper agitation by sonication process was done to ensure uniform dispersion and stability of the nano-lubricants in the refrigeration system. No surfactant was added to the mixtures as this may adversely influence their thermal conductivity and performance. The prepared nanoparticle-lubricant mixtures $\left(\mathrm{TiO}_{2}-\mathrm{MO}\right.$, $\mathrm{Al}_{2} \mathrm{O}_{3}-\mathrm{MO}$, and $\mathrm{SiO}_{2}-\mathrm{MO}$ ) were later injected into the compressor, through the compressor service port provided. Fig. 3 showed images of the selected nanoparticle-lubricant mixtures (i.e. $\mathrm{TiO}_{2}-\mathrm{MO}$, $\mathrm{Al}_{2} \mathrm{O}_{3}-\mathrm{MO}$, and $\mathrm{SiO}_{2}-\mathrm{MO}$ ) held in test tubes.

\section{Experimental setup and procedure}

The experimental setup utilized for this examination consists of a domestic refrigerator with an inherent 100W-R134a compressor, air-cooled condenser, dryer, capillary tube and an evaporator subcomponent (Fig. 4). Fig. 4 illustrates the schematic diagram, specification of the experimental setup given in Table 1 , while the experimental setup appears in Fig. 5. The apparatus was incorporated with valves that are required for charging and releasing of refrigerants, and to enable the fitting of proper pressure gauges at desired locations. Digital thermocouples $\mathrm{K}$ and pressure gauges were incorporated into the experimental setup to capture temperature and pressure of the refrigerant. The power utilization of the refrigerator compressor were measured with digital wattmeter having $\pm 1 \%$ measurement accuracy. Characteristics of these measuring instruments are shown in Table 2. The thermocouples and pressure gauges were adopted to measure the different temperatures and pressures respectively at the specified locations at $30 \mathrm{~min}$ interval for a total observation period of $180 \mathrm{~min}$. The test location (experimental site) is in a tropical environment (Nigeria), having an ambient air temperature range of $29-32{ }^{\circ} \mathrm{C}$ and relative humidity of $51 \%$. The room temperature was captured using Rototherm surface temperature thermometers (Model BL301), having a range of $0-400^{\circ} \mathrm{C}$. The experimental room was fitted with a 10 ton air-conditioner, to maintained the room condition (ambient temperature and relative humidity), throughout the experimental trials.

Tests were initially carried out for the manufacturer specified charge of $100 \mathrm{~g}$ for the R134a refrigerant utilizing polyol ester (POE) based compressor oil. The $100 \mathrm{~g}$ charge was to assess the compressor power consumption, cooling capacity, COP, compressor discharge temperature,pulldown time, irreversibility in parts (compressor, condenser, evaporator and capillary tube), total irreversibility and second law efficiency, according to Padmanabhan and Palanisamy (2012), and Gill and Singh (2017a). This was done to generate the baseline data upon which nano-lubricant based data could be compared. After running the tests with R134a/POE lubricant, the polyol-ester (POE) oil was later replaced 
(a)

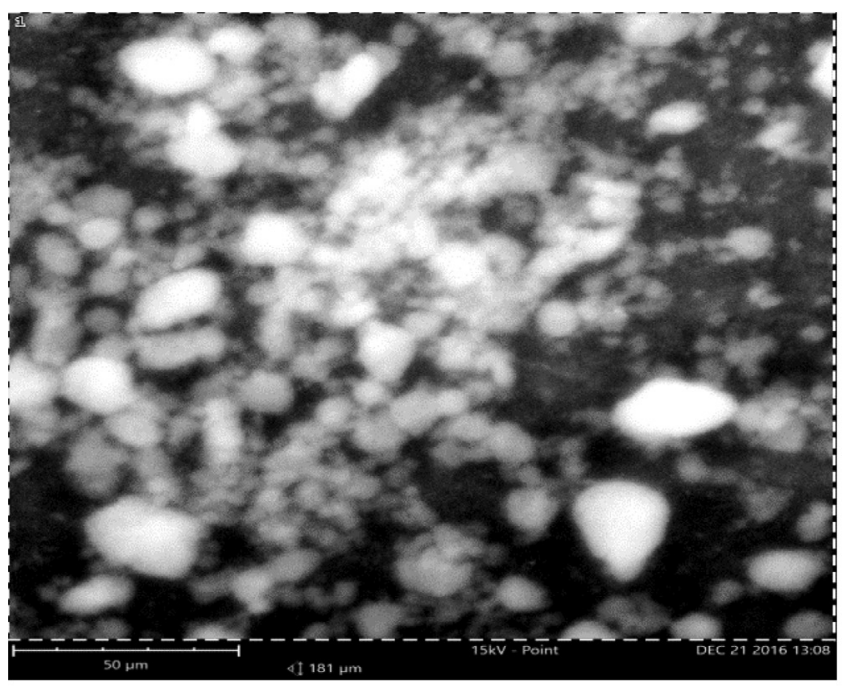

(b)

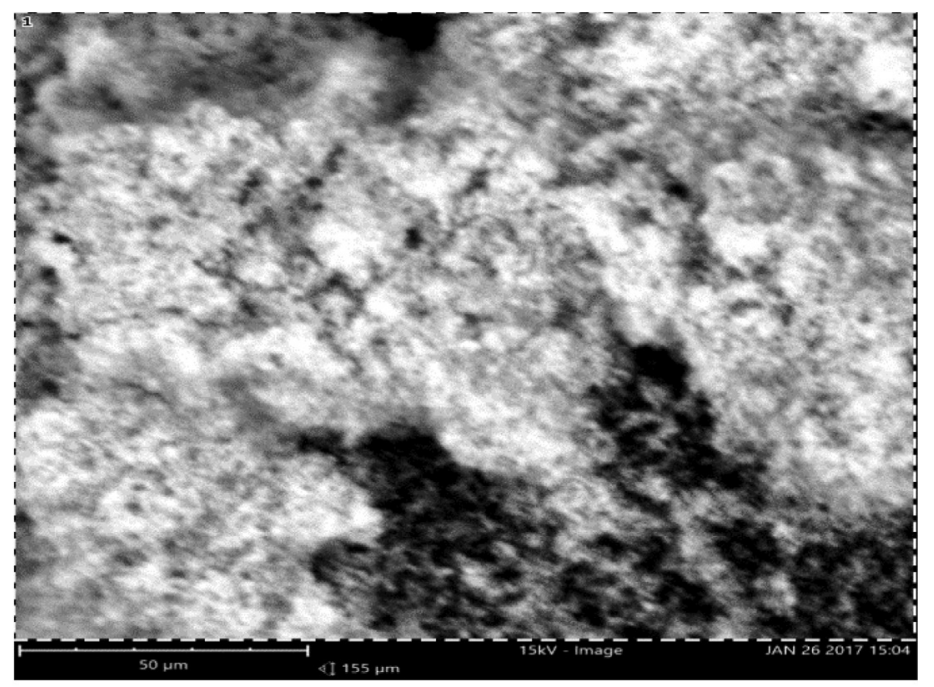

(c)

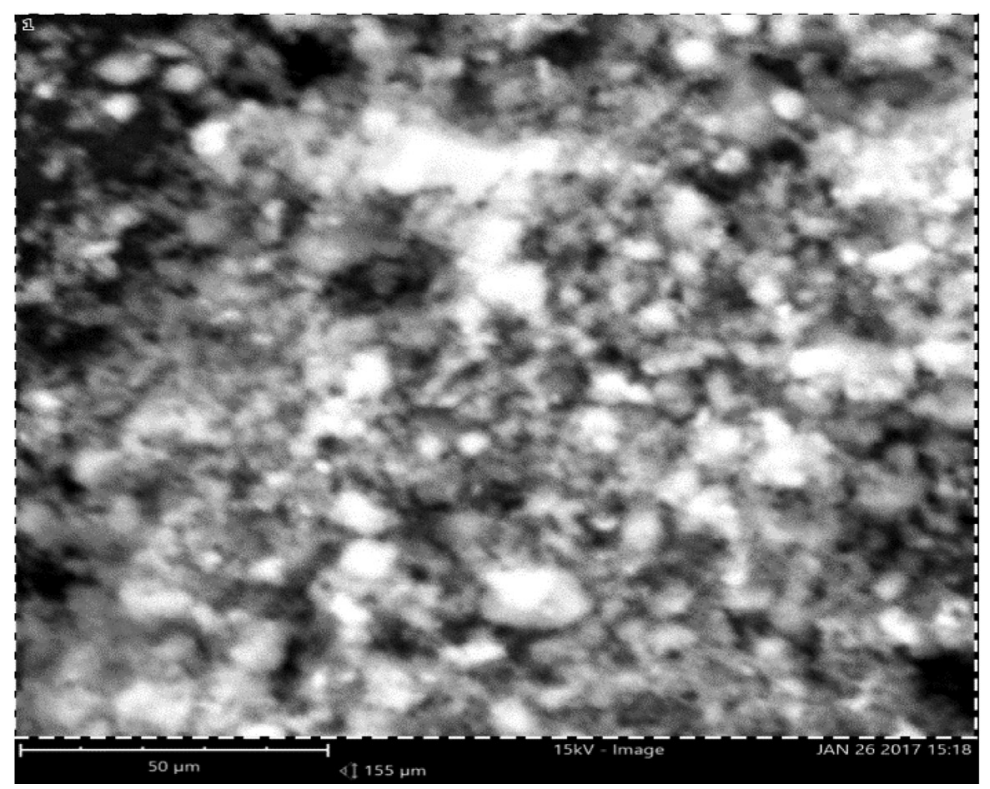

Fig. 1. Scanning electron microscopy of: (a) $\mathrm{Al}_{2} \mathrm{O}_{3}(13 \mathrm{~nm})$, (b) $\mathrm{TiO}_{2}(15 \mathrm{~nm})$, and (c) $\mathrm{SiO}_{2}(5-15 \mathrm{~nm})$, nanoparticles.

Table 2

Characteristics of the measuring instruments.

\begin{tabular}{lllll}
\hline S/N & Measured data & Manufacturers specification & Range & Uncertainty \\
\hline 1 & Temperature & Digital thermocouple $\mathrm{K}$ & $-50{ }^{\circ} \mathrm{C}-750{ }^{\circ} \mathrm{C}$ & $\pm 1{ }^{\circ} \mathrm{C}$ \\
2 & Pressure & Digital pressure gauge & $5-5000 \mathrm{kPa}$ & $\pm 1 \%$ \\
3 & Power consumption & Digital Watt/Watt-h-meter & $1-3000 \mathrm{~W}(0.0001-999.9 \mathrm{~kW} \mathrm{~h})$ & $\pm 1 \%$ \\
4 & Flow meter & Digital flow meter & $0-20 \mathrm{~g} / \mathrm{s}$ & $\pm 0.2 \%$ \\
\hline
\end{tabular}

with mineral oil (MO), and then with MO-nanoparticle mixtures of the same concentrations. Trials were later repeated by utilizing optimal charge of LPG (i.e. at $40 \mathrm{~g}$ ) as described in Ohunakin et al. (2017), with mineral oil and then with the selected nanoparticlelubricant mixtures ( $\mathrm{TiO}_{2}-\mathrm{MO}, \mathrm{Al}_{2} \mathrm{O}_{3}-\mathrm{MO}$, and $\mathrm{SiO}_{2}-\mathrm{MO}$ ), at $0.2 \mathrm{~g} / \mathrm{L}$ concentration of the selected nanoparticle (Ohunakin et al., 2017). The tests of each nanoparticle-lubricant mixture, were conducted to assess the optimal nanoparticle-lubricant mixture with the criterion of highest COP and second law efficiency in line with recommendations of Poggi et al. (2008). After each test, the compressor was flushed with pure mineral oil repeatedly until the system becomes clean and free of any left over of nanoparticles. The dryer component was changed each time the compressor oil was to be changed. Each of the selected nanoparticle-compressor 


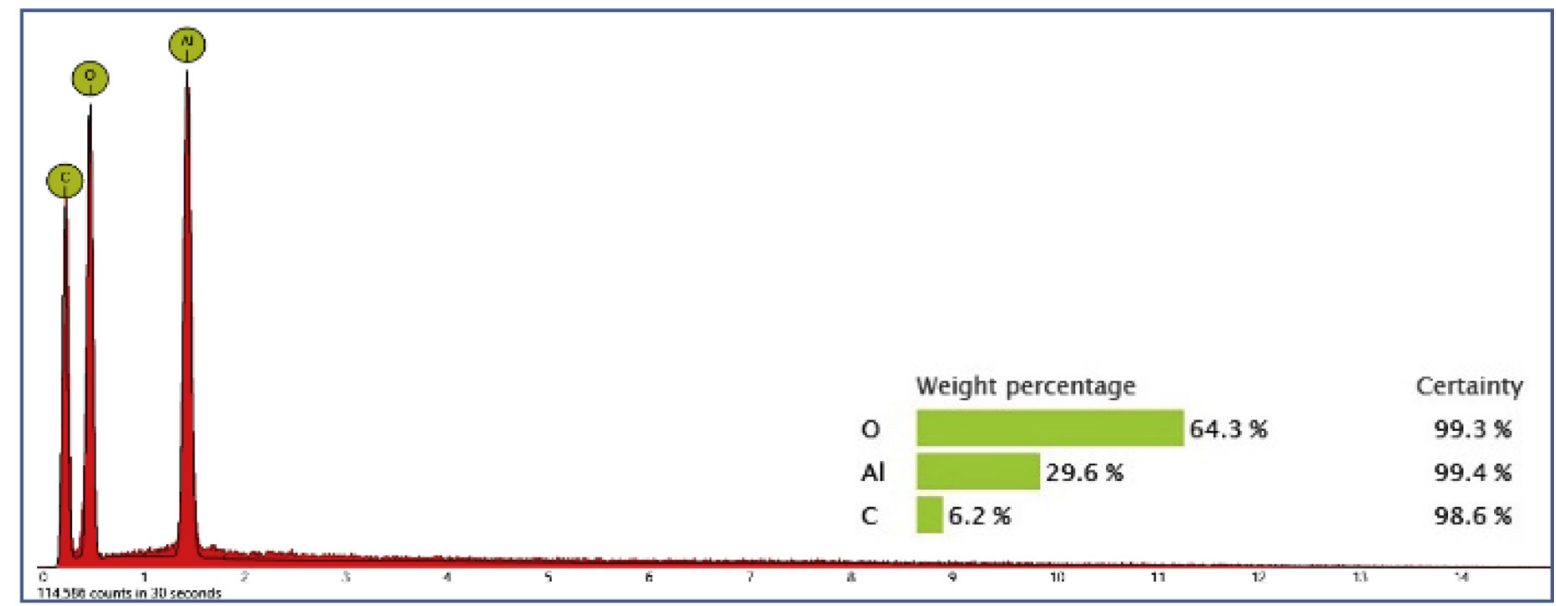

a)

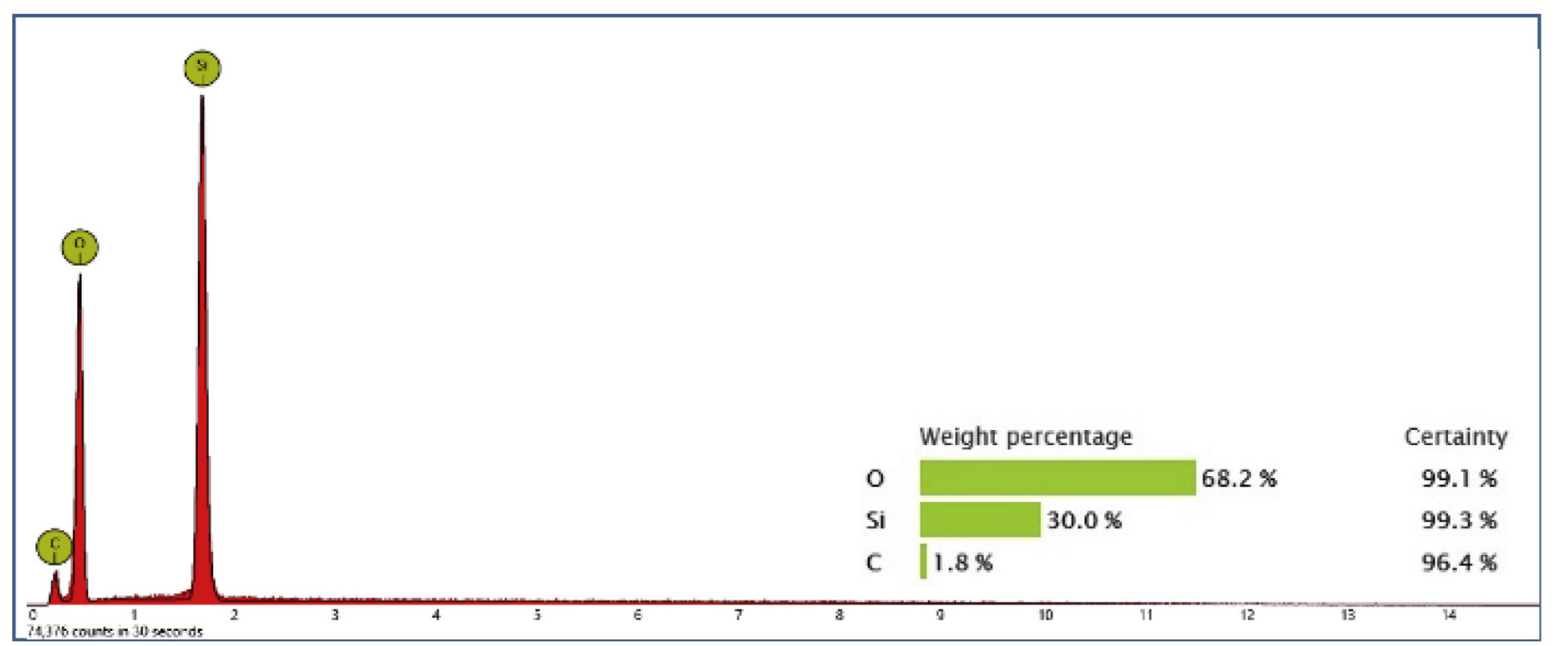

b)

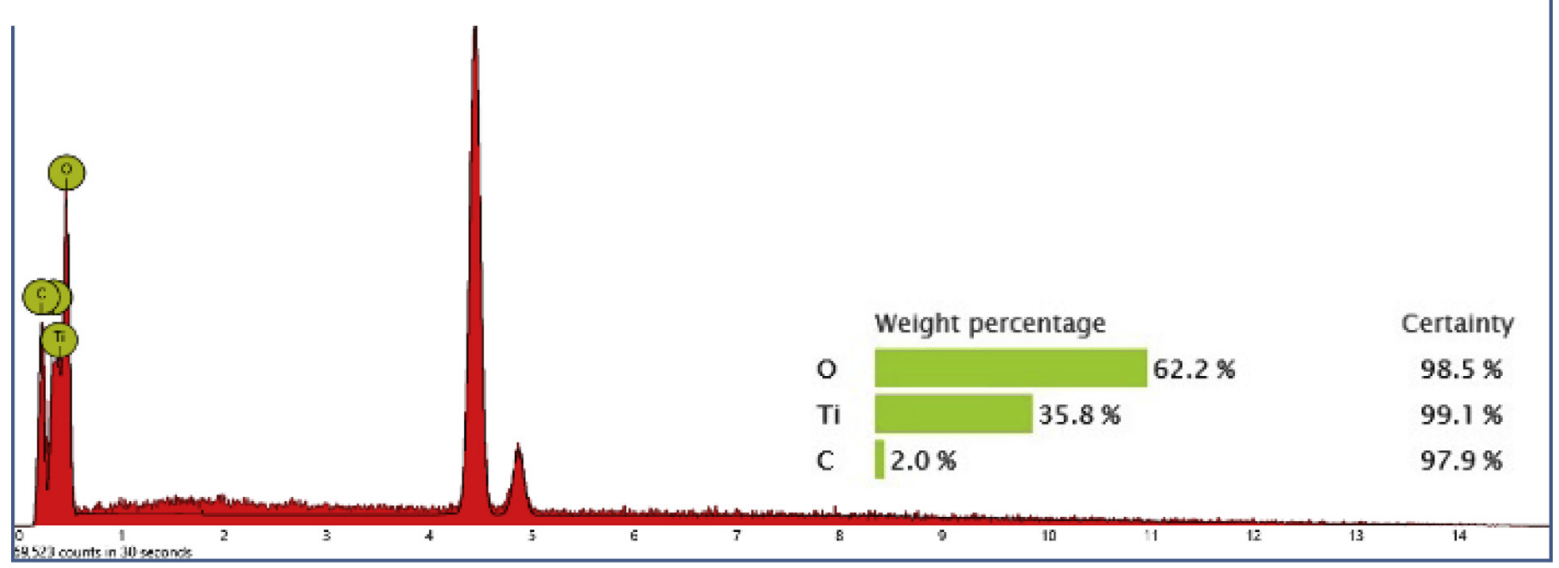

c)

Fig. 2. EDX diffractogram of: (a) $\mathrm{Al}_{2} \mathrm{O}_{3}$, (b) $\mathrm{TiO}_{2}$, and (c) $\mathrm{SiO}_{2}$ nanoparticles.

lubricants was mechanically agitated using an ultrasonic vibrator (Branson $\mathrm{M} 2800 \mathrm{H}$ ) to entirely separate the nanoparticles, thereby enhancing the uniformity of distribution inside the lubricant. The nanoparticle-lubricant mixtures were later infused separately into the refrigerator compressor. LPG refrigerant used for the study was obtained locally and has a purity of $99.7 \%$. The characteristics of the nanoparticles used for the experiment are as indicated in Table 3, while Table 4 showed the properties of the lubricating oil. The nanoparticles were measured on a digital weighing balance (OHAUS Pioneer TM PA114) having a measuring range of 
Table 3

Characteristics of the selected nanoparticles.

\begin{tabular}{llllll}
\hline $\mathrm{S} / \mathrm{N}$ & Particle type & Particle Size $(\mathrm{nm})$ & Purity $(\%)$ & Manufacturer & P code \\
\hline 1 & Aluminium oxide $\left(\mathrm{Al}_{2} \mathrm{O}_{3}\right)$ & $13 \mathrm{~nm}$ & 99.8 & Aldrich Chemistry & 1001922903 \\
2 & Silicon dioxide $\left(\mathrm{SiO}_{2}\right)$ & $5-15 \mathrm{~nm}$ & 99.5 & Aldrich Chemistry & 1001795587 \\
3 & Titanium dioxide $\left(\mathrm{TiO}_{2}\right)$ & $15 \mathrm{~nm}$ & 99.7 & Alfa Aesar & - \\
\hline
\end{tabular}

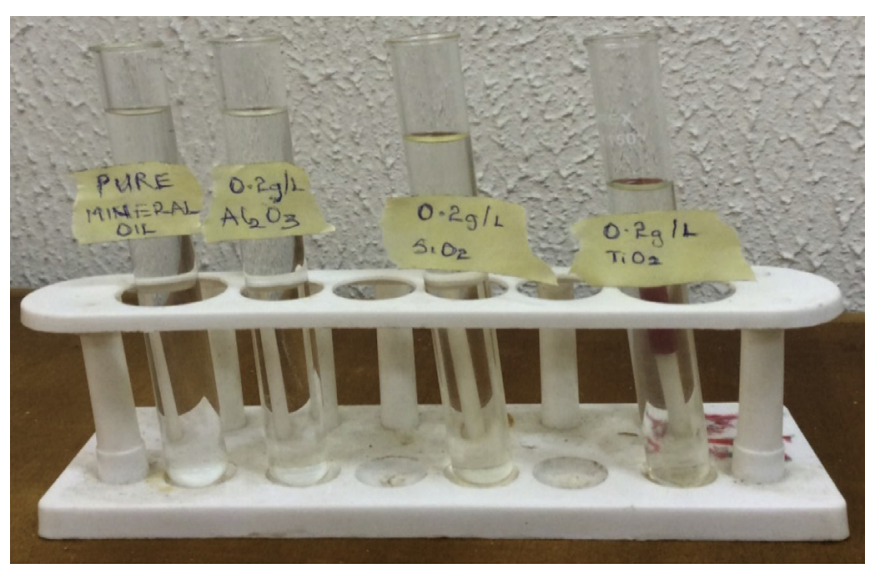

Fig. 3. Pure mineral oil and prepared nanoparticle-lubricant mixtures $\left(\mathrm{Al}_{2} \mathrm{O}_{3}-\mathrm{MO}\right.$, $\mathrm{SiO}_{2}-\mathrm{MO}$ and $\mathrm{TiO}_{2}-\mathrm{MO}$ ).

0.0001-110g, while the LPG refrigerant was measured using a digital weighing balance (CAMRY ACS-30-ZC41) having a measured range of 5-30,000 g. A vacuum pump (Sigma B-42: 1/4 HP Vacuum pump) was adopted for extracting spent refrigerant from the
Table 4

Characteristics of the lubricating oil.

\begin{tabular}{lll}
\hline S/N & Lubricating oil characteristics & Units \\
\hline 1 & Oil type & Capella mineral oil \\
2 & ISO viscosity grade & 68 \\
3 & Flashpoint & $-36{ }^{\circ} \mathrm{C}$ \\
4 & Density at $15^{\circ} \mathrm{C} \mathrm{kg} / \mathrm{L}$ & 0.91 \\
5 & Kinematic viscosity $\left(\mathrm{mm}^{2} / \mathrm{s}\right)$ at $40{ }^{\circ} \mathrm{C}$ & 68 \\
6 & Kinematic viscosity $\left(\mathrm{mm}^{2} / \mathrm{s}\right)$ at $100{ }^{\circ} \mathrm{C}$ & 6.8 \\
7 & Viscosity index & 22 \\
8 & Code & 041562 \\
\hline
\end{tabular}

system after each trial, in preparation for another experiment. Each trial of the experiment was repeated five times to ensure repeatability with reference to conditions given in Table 5 .

\subsection{Uncertainty analysis}

The uncertainties for this work were estimated using Schultz and Cole (1979) method. According to Schultz and Cole (1979) method and Sheikholeslami and Ganji (2016), the uncertainty of the desired parameter like $\mathrm{R}$ would be derived

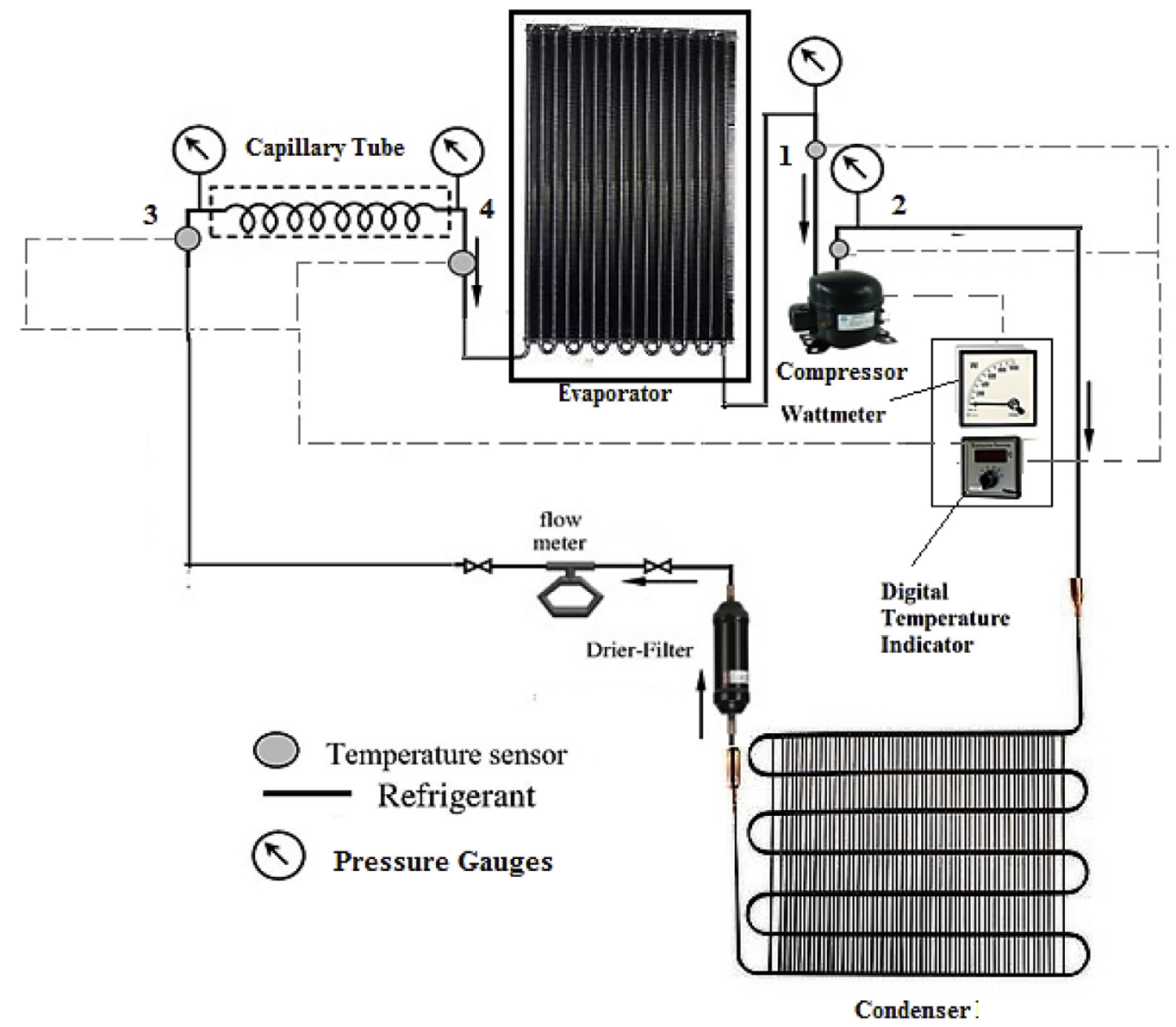

Fig. 4. Schematic diagram of experimental setup. 


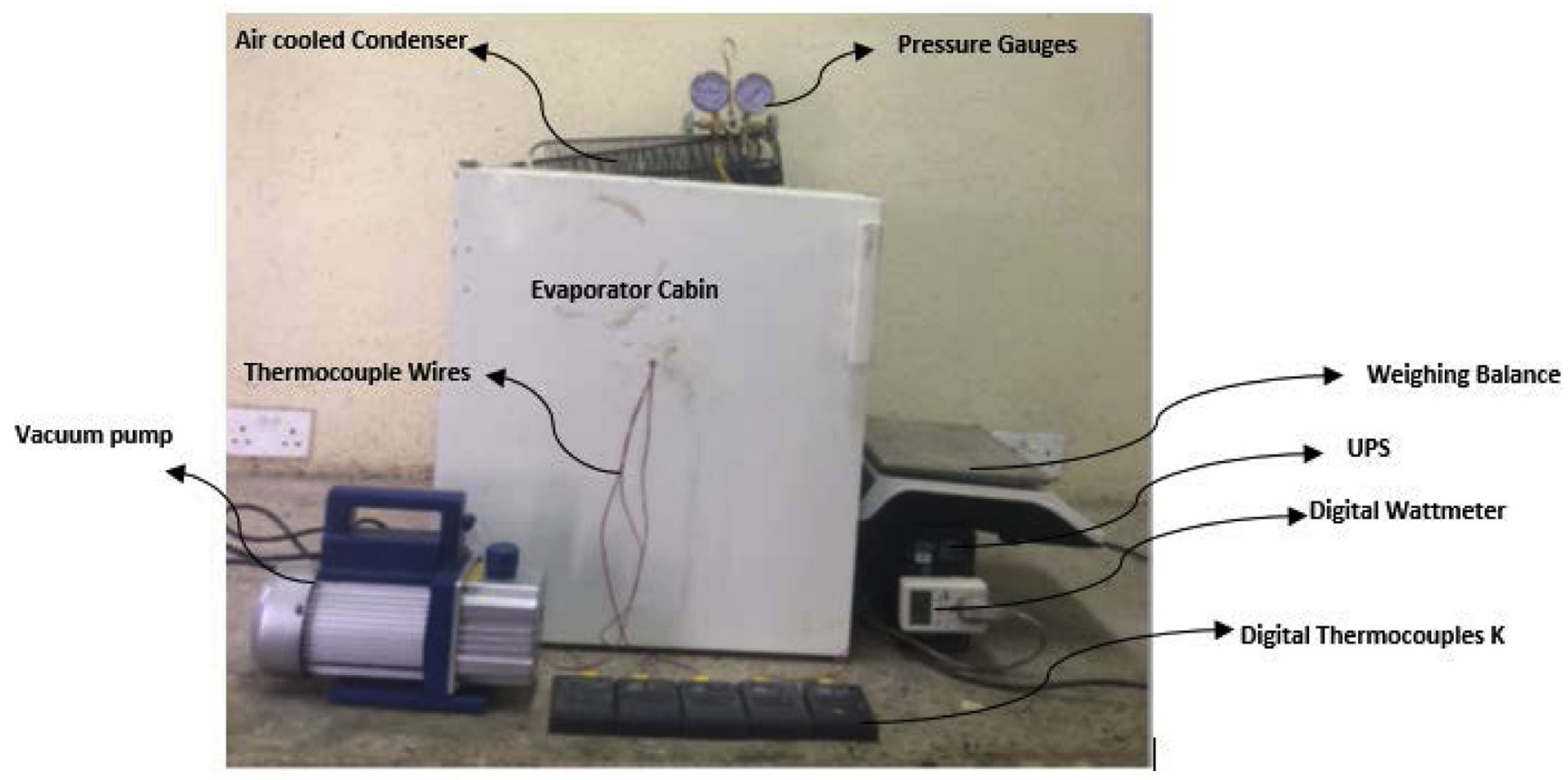

Fig. 5. Experimental setup.

Table 5

Range of experimental conditions.

\begin{tabular}{llll}
\hline $\mathrm{S} / \mathrm{N}$ & Parameter & Range of experiment \\
\hline 1 & Refrigerant name & $\mathrm{R} 134 \mathrm{a}$ & $\mathrm{LPG}(60: 40$ Propane-Butane Mixture $)$ \\
2 & Refrigerant charge & $100 \mathrm{~g}$ & $40 \mathrm{~g}$ \\
3 & Compressor lubricant & $\mathrm{POE}$ & Mineral oil, $\mathrm{Al}_{2} \mathrm{O}_{3}, \mathrm{SiO}_{2}$, and $_{\mathrm{TiO}}$, nanolubricants \\
4 & Nanoparticle lubricant concentration & $0.0 \mathrm{~g} / \mathrm{L}\left(\mathrm{TiO}_{2}\right)$ & $0.2 \mathrm{~g} / \mathrm{L}\left(\mathrm{TiO}_{2}\right)$ \\
5 & Test environment temperature & $29-32^{\circ} \mathrm{C}$ & $29-32{ }^{\circ} \mathrm{C}$ \\
6 & Capillary tube length & $2 \mathrm{~m}$ & $2 \mathrm{~m}$ \\
7 & Evaporator type & Air cooled & Air cooled \\
\hline
\end{tabular}

Table 6

Uncertainty in calculated parameters.

\begin{tabular}{lll}
\hline S/N & Parameters & Absolute uncertainty \\
\hline 1 & $T_{1}$ & $\pm 0 .{ }^{\circ} \mathrm{C}$ \\
2 & $T_{2}$ & $\pm 0.2^{\circ} \mathrm{C}$ \\
& $T_{3}$ & $\pm 0.2^{\circ} \mathrm{C}$ \\
3 & $T_{4}$ & $\pm 0.2{ }^{\circ} \mathrm{C}$ \\
4 & $P_{1,} P_{4}$ & $\pm 2 \mathrm{kPa}$ \\
5 & $P_{2,} P_{3}$ & $\pm 5 \mathrm{kPa}$ \\
6 & $I_{\text {comp }}$ & $\pm 1.52 \mathrm{~W}$ \\
7 & $I_{\text {cond }}$ & $\pm 1.20 \mathrm{~W}$ \\
8 & $I_{\text {cap }}$ & $\pm 0.72 \mathrm{~W}$ \\
9 & $I_{\text {evap }}$ & $\pm 1.01 \mathrm{~W}$ \\
10 & $I_{\text {total }}$ & $\pm 2.29 \mathrm{~W}$ \\
11 & $\eta_{\text {ex }}$ & $\pm 1.23 \%$ \\
12 & COP & $\pm 2.13 \%$ \\
\hline
\end{tabular}

using Eq. (1):

$U_{R}=\left[\sum_{i=1}^{n}\left(\frac{\partial R}{\partial_{V_{i}}} U_{V_{i}}\right)^{2}\right]^{\frac{1}{2}}$

Where $U_{R}$ is the total uncertainty, $U_{V_{i}}$ is the uncertainty of each independent variable and $n$ is the total number of variables (Schultz and Cole, 1979). Table 6 illustrates the uncertainties of the parameters. For all the parameters, the maximum percentage uncertainty was less than $3 \%$.

\section{Exergy and energy analysis}

Exergy provides a measure of how far a particular system deviates from the given state and the reference state. Overall balances of exergy is illustrated in Fig. 6. In the real process of a system, some of the exergies are consumed. Thus, the total exergy available at the output of a system $\left(E_{\text {out }}\right)$ is less than the total Exergy at the inlet of a system $\left(E_{\text {in }}\right)$. This amount of exergy that is consumed is due to the irreversibilities in a system and is termed as the total irreversibility $\left(I_{\text {total }}\right)$. The general exergy balance can be expressed in Eq. (2) (Gill and Singh, 2017a):

$E_{\text {in }}-E_{\text {out }}=I_{\text {total }}$

where $E_{\text {in }}$ and $E_{\text {out }}$ are the total Exergies transferred by heat, work and mass.

Eq. (2) can also be written as exergy balance for a control volume in a steady state process as expressed in Eq. (3):

$$
\begin{aligned}
I_{\text {total }}= & \sum_{\text {in }} \xi \cdot e-\sum_{\text {out }} \xi \cdot e+\sum\left[\dot{Q}\left(1-\frac{T_{0}}{T_{\mathrm{b}}}\right]_{\text {in }}\right. \\
& -\sum\left[Q\left(1-\frac{T_{0}}{T_{\mathrm{b}}}\right]_{\text {out }}+\sum W_{\text {in }}-\sum W_{\text {out }}\right.
\end{aligned}
$$

where the first two terms are the stream exergy flows in which $\xi$ and $e$ are the mass flow rate of refrigerant and specific exergy, respectively. The next two terms are heat transfer exergy flows, in which $\dot{Q}$ is the heat transfer rate through the boundary at temperature $T_{\mathrm{b}}$; the last two terms are work exergy flows, where $W$ is the work rate. Potential, kinetic and chemical exergies are supposed to 


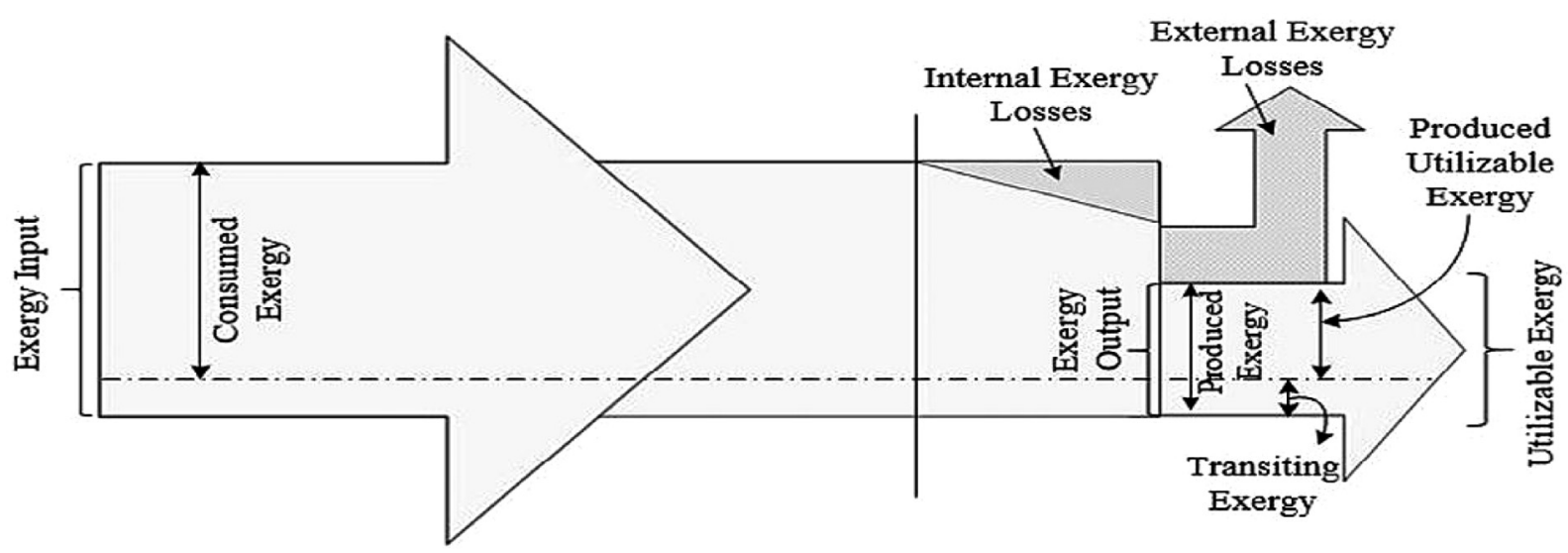

Fig. 6. Graphical presentation of general Exergy balance (Gill and Singh, 2017a).

be insignificant because of the elevation; also speed and chemical changes are negligible respectively in a refrigeration system, while only the physical exergy is taken into consideration in the system. Specific exergy of a fluid circulating in the vapor compression refrigeration system may be expressed as shown in Eq. (4):

$e=\left(h-T_{0} S\right)-\left(h_{0}-T_{0} S_{0}\right)$

where $S_{0}$ and $h_{0}$ are the entropy and enthalpy values of the dead state of the refrigerant at temperature $T_{0}$.

For the above exergy equations performed on primary components (compressor, evaporator, condenser and capillary tube) of the domestic refrigerator system given in Fig. 4, the component-wise irreversibility can be determined from Eqs. (5)-(8) (Padmanabhan and Palanisamy, 2012). The thermophysical properties of the refrigerants used in this analysis were acquired from the property database REFPROP 9.1.

\subsection{Irreversibility in compressor $\left(\mathrm{I}_{\text {comp }}\right)$}

$I_{\text {comp }}=T_{0}\left\{\xi\left(S_{2}-S_{1}\right)+\left[W_{\text {Comp }}-\xi\left(h_{2}-h_{1}\right)\right] / T_{0}\right\}$

$S_{2}$ and $h_{2}$ are the entropy and specific enthalpy of the refrigerant at the exit of the compressor, while $S_{1}$ and $h_{1}$ are the entropy and enthalpy of the refrigerant at the inlet to the compressor. In addition, $T_{0}$ is the ambient temperature.

\subsection{Irreversibility in condenser $\left(\mathrm{I}_{\text {cond }}\right)$}

$I_{\text {cond }}=T_{0}\left\{\xi\left[\left(\begin{array}{ll}S_{2} & \left.\left.-S_{3}\right)-\frac{\left(h_{2}-h_{3}\right.}{}\right) \\ T_{\text {cond }}\end{array}\right]\right\}\right.$

where $S_{3}$ and $h_{3}$ are the entropy and specific enthalpy of the refrigerant at the exit of the condenser, and $T_{\text {cond }}$ is the condenser temperature.

\subsection{Irreversibility in capillary tube $\left(\mathrm{I}_{\text {cap }}\right)$}

$I_{\text {cap }}=T_{0}\left\{\xi\left[\left(S_{4}-S_{3}\right)-\frac{\left(h_{4}-h_{3}\right)}{T_{\text {cond }}}\right]\right\}$

where $S_{4}$ and $h_{4}$ are the entropy and specific enthalpy of the refrigerant at the exit of the capillary tube.

\subsection{Irreversibility in evaporator ( $\mathrm{I}_{\text {evap }}$ )}

$\mathbf{I}_{\text {evap }}=T_{0}\left[\xi\left(S_{1}-S_{4}\right)-\frac{\left(h_{1}-h_{4}\right)}{T_{\text {evap }}}\right]$

where $T_{\text {evap }}$ is the evaporator temperature. Total irreversibility can also be written as:

$\mathbf{I}_{\text {total }}=I_{\text {comp }}+I_{\text {cond }}+I_{\text {cap }}+I_{\text {evap }}$

The second law of efficiency of the vapor compression refrigeration system can be expressed as the ratio of the actual COP of the cycle to the maximum COP of the cycle under the same conditions. The second law of efficiency $\left(\eta_{\mathrm{ex}}\right)$ of the vapor compression refrigeration system can be defined as:

$\eta_{\mathbf{e x}}=\frac{E_{\text {out }}}{E_{\text {in }}}=1-\frac{I_{\text {total }}}{E_{\text {in }}}$

The second law of efficiency can further be written as:

$\eta_{\mathbf{e x}}=\frac{E_{\text {out }}}{E_{\text {in }}}=1-\frac{I_{\text {total }}}{W_{\text {Comp }}}$

For a reversible process, the second law of efficiency is equal to one, and may be less than one in another case.

The cooling capacity of the evaporator on refrigerant side as i.e.

$Q=\xi\left(h_{1}-h_{4}\right)(\mathrm{kW})$

The coefficient of performance of the domestic refrigerator is given by Eq. (13):

$$
\begin{aligned}
& \mathrm{COP}=\frac{Q}{W_{\text {Comp }}} \\
& \text { In Eq. (13), } W_{\text {Comp }} \text { is the compressor power consumption }
\end{aligned}
$$

\section{Result and discussions}

Results of the steady-state pressure and temperature readings obtained for every trial during a closed door, no load, and continuous cyclic (i.e. running without ON/OFF) working condition of the compressor, were employed to select the required thermodynamic properties of the LPG and R134a refrigerants from NIST REFPROP software (version 9.1). The LPG refrigerant is a 60/40 PropaneButane mixture. The thermo-physical properties of R134a and LPG were also imported from NIST REFPROP software version 9.1, and utilized to calculate the parameters of the energetic and exergetic performance analysis using Eqs. (4)-(12). The calculated energetic and exergetic performance parameters of the domestic refrigerator, 
Table 7

Comparison of energetic performance parameters between R134a/POE lubricant and LPG with the selected lubricants (POE, $\mathrm{MO}, \mathrm{Al}_{2} \mathrm{O}_{3}-\mathrm{MO}$, $\mathrm{TiO}_{2}-\mathrm{MO}$ and $\mathrm{SiO}_{2}-\mathrm{MO}$ at $0.2 \mathrm{~g} / \mathrm{L}$ concentration of nanoparticles).

\begin{tabular}{|c|c|c|c|c|c|c|c|c|c|}
\hline $\mathrm{S} / \mathrm{N}$ & Refrigerant & Lubricant & Concentration of nanoparticle & $W_{\text {comp }}(\mathrm{W})$ & COP & $T_{\mathrm{D}}\left({ }^{\circ} \mathrm{C}\right)$ & $Q_{c}(W)$ & $I_{\text {total }}(\mathrm{W})$ & $\eta_{\mathrm{ex}}(\%)$ \\
\hline 2 & LPG & MO & $0.0 \mathrm{~g} / \mathrm{L}$ & 72.70 & 2.37 & 60 & 172.32 & 45.40 & 37.56 \\
\hline 4 & LPG & $\mathrm{TiO}_{2}-\mathrm{MO}^{\mathrm{a}}$ & $0.2 \mathrm{~g} / \mathrm{L}$ & 63.20 & 2.97 & 54 & 187.70 & 36.66 & 42.00 \\
\hline 5 & LPG & $\mathrm{SiO}_{2}-\mathrm{MO}$ & $0.2 \mathrm{~g} / \mathrm{L}$ & 64.52 & 2.96 & 50 & 190.98 & 38.12 & 40.91 \\
\hline
\end{tabular}

a Optimum nano-based lubricant.

using $100 \mathrm{~g}$ charge of $\mathrm{R} 134 \mathrm{a} / \mathrm{POE}$, and $40 \mathrm{~g}$ charge of LPG refrigerants with the selected lubricants $\left(\mathrm{MO}, \mathrm{Al}_{2} \mathrm{O}_{3}-\mathrm{MO}\right.$, $\mathrm{TiO}_{2}-\mathrm{MO}$, and $\mathrm{SiO}_{2}-\mathrm{MO}$ at $0.2 \mathrm{~g} / \mathrm{L}$ concentration of the nanoparticles) are shown in Table 7.

\subsection{Parameters of the energetic performance analysis of the domestic refrigeration system}

The parameters of the energetic performance analysis of the domestic refrigeration system, using $100 \mathrm{~g}$ charge of R134a/POE lubricant and $40 \mathrm{~g}$ charge of LPG refrigerants with the selected lubricants ( $\mathrm{MO}, \mathrm{Al}_{2} \mathrm{O}_{3}-\mathrm{MO}, \mathrm{TiO}_{2}-\mathrm{MO}$, and $\mathrm{SiO}_{2}-\mathrm{MO}$ with $0.2 \mathrm{~g} / \mathrm{L}$ of the nanoparticles) were compared in Figs. 7-9. The pressure ratio and the compressor power consumption of the domestic refrigerator using $100 \mathrm{~g}$ charge of R134a/POE lubricant, and $40 \mathrm{~g}$ charge of LPG refrigerants with the lubricants ( $\mathrm{MO}, \mathrm{Al}_{2} \mathrm{O}_{3}-\mathrm{MO}, \mathrm{TiO}_{2}-\mathrm{MO}$, and $\mathrm{SiO}_{2}-\mathrm{MO}$ with $0.2 \mathrm{~g} / \mathrm{L}$ of the nanoparticle) were compared in Fig. 7(a) and (b). Fig. 7(a) showed that the LPG refrigerant with pure MO and baseline mixture (i.e R134a/POE) has pressure ratio values of 5.31 and 5.41 respectively. Reduction of the pressure ratio of LPG-MO in comparison with R134a/POE occurs in accordance with Arun Kumar et al. (2014).In addition, Bi et al. (2011) concluded that the addition of nanoparticles further reduces the suction and discharge pressure of the compressor, as a result of which the pressure ratio and the compressor power consumption are further reduced in comparison with the baseline working fluids (Kumar and Elansezhian, 2014; Gill et al., 2018; Bolaji et al., 2014). Hence, pressure ratio of LPG refrigerants with the lubricants $\left(\mathrm{Al}_{2} \mathrm{O}_{3}-\mathrm{MO}, \mathrm{TiO}_{2}-\right.$ $\mathrm{MO}$, and $\mathrm{SiO}_{2}-\mathrm{MO}$ with $0.2 \mathrm{~g} / \mathrm{L}$ of the nanoparticle) was found to be lower than LPG-MO lubricant by about $1.12-5.66 \%$. The least pressure ratio value of 5.0 was recorded with $\mathrm{TiO}_{2}-\mathrm{MO}$ lubricant $(0.2 \mathrm{~g} / \mathrm{L}$ of nanoparticle concentration) which gave $7.4 \%$ reduction from baseline mixture (i.e. R134a/POE) which was also having the highest pressure ratio value (i.e. 5.41). The pressure ratio values of 5.22 for $\mathrm{SiO}_{2}-\mathrm{MO}, 5.31$ for pure $\mathrm{MO}$ and 5.25 for $\mathrm{Al}_{2} \mathrm{O}_{3}-\mathrm{MO}$ were seen within the test rig (see Fig. 7(a)). Similarly, Fig 7(b) shows that the compressor power consumption of the domestic refrigerator using LPG refrigerants with the lubricants $\left(\mathrm{MO}, \mathrm{Al}_{2} \mathrm{O}_{3}-\mathrm{MO}\right.$, $\mathrm{TiO}_{2}-\mathrm{MO}$, and $\mathrm{SiO}_{2}-\mathrm{MO}$ with $0.2 \mathrm{~g} / \mathrm{L}$ of the nanoparticle) was found lower than baseline mixture (R134a/POE) in the range of 2.69$15.87 \%$ due to lower pressure ratio. Furthermore, the least compressor power consumption was observed with $\mathrm{LPG}$ using $\mathrm{TiO}_{2}-\mathrm{MO}$ lubricant $(0.2 \mathrm{~g} / \mathrm{L}$ of nanoparticle concentration) due to least pressure ratio and found to be $15.87 \%$ lower than with $100 \mathrm{~g}$ charge of R134a/POE lubricant, as shown in Table 7. Also, the daily energy consumptions for all the mixtures seen in Fig. 7(c).

The comparison of the cooling capacity of the test rig with the $100 \mathrm{~g}$ charge of R134a/POE lubricant and $40 \mathrm{~g}$ charge of LPG refrigerants/lubricants (MO, with $0.2 \mathrm{~g} / \mathrm{L}$ of the nanoparticle) is shown in Fig. 8(a). It was observed that LPG refrigerant has higher latent heat than the $100 \mathrm{~g}$ charge of R134a. Furthermore, the heat transfer capability of nanofluids (base liquids homogenized with nanoparticles) were enhanced immensely than the pure base liquids (Ohunakin et al., 2017). Among these lines, the cooling ca- (a)

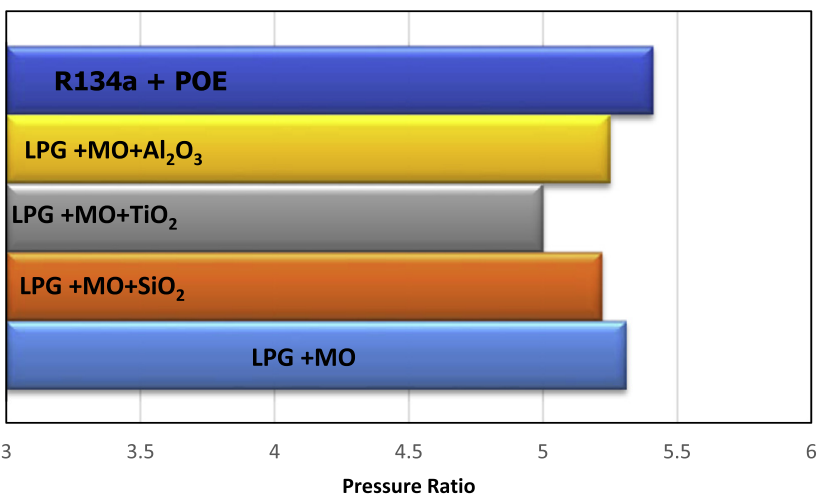

(b)

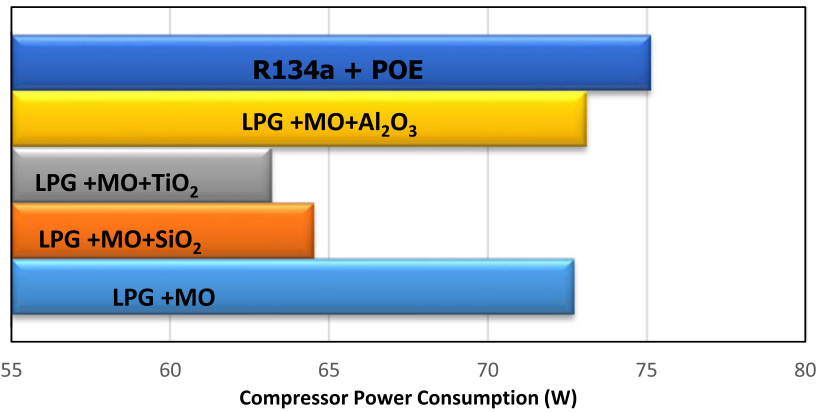

(c)

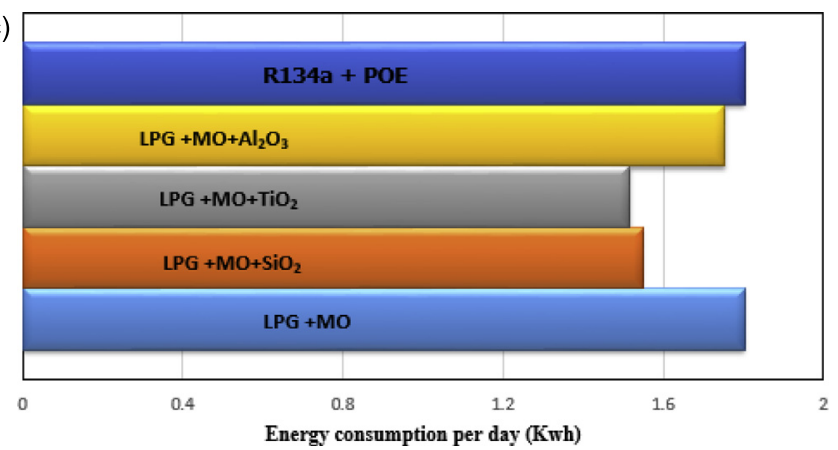

Fig. 7. (a) Comparison of pressure ratio of R134a/POE lubricant and LPG refrigerants with the selected lubricants (POE, $\mathrm{MO}, \mathrm{Al}_{2} \mathrm{O}_{3}-\mathrm{MO}, \mathrm{TiO}_{2}-\mathrm{MO}$ and $\mathrm{SiO}_{2}-\mathrm{MO}$ at $0.2 \mathrm{~g} / \mathrm{L}$ concentration of nanoparticles). (b) Comparison of compressor power consumption between R134a/POE lubricant and LPG refrigerants with the selected lubricants (POE, MO, $\mathrm{Al}_{2} \mathrm{O}_{3}-\mathrm{MO}, \mathrm{TiO}_{2}-\mathrm{MO}$ and $\mathrm{SiO}_{2}-\mathrm{MO}$ at $0.2 \mathrm{~g} / \mathrm{L}$ concentration of nanoparticles). (c) Comparison of energy consumption per day between R134a/POE lubricant and LPG refrigerants with the selected lubricants (POE, $\mathrm{MO}, \mathrm{Al}_{2} \mathrm{O}_{3}-\mathrm{MO}$, $\mathrm{TiO}_{2}-\mathrm{MO}$ and $\mathrm{SiO}_{2}-\mathrm{MO}$ at $0.2 \mathrm{~g} / \mathrm{L}$ concentration of nanoparticles).

pacity of domestic refrigerator using LPG refrigerant with selected lubricants were higher than R134a/POE lubricant between 1.41 and $33.81 \%$. Furthermore, Table 8 showed that the cooling capacity of the domestic refrigerator using the $40 \mathrm{~g}$ charge of LPG refrigerant infused with $\mathrm{TiO}_{2}$-MO lubricant $\left(0.2 \mathrm{~g} / \mathrm{L}\right.$ of $\left.\mathrm{TiO}_{2}\right)$ was $31.52 \%$ higher than with $100 \mathrm{~g}$ charge of R134a/POE lubricant. 
Table 8

$W_{\text {Comp }}$, COP, $Q_{C}, I_{\text {tot }}$ and $\eta$ variations of LPG with MO and $\mathrm{TiO}_{2}-\mathrm{MO}$ lubricants taking R134a with POE lubricant as a baseline.

\begin{tabular}{|c|c|c|c|c|c|c|}
\hline Sr. no & Nano based lubricant & $\begin{array}{l}\left|\left(\frac{W_{\text {comp R134a }}-W_{\text {complLPG }}}{W_{\text {comp R } 134 \mathrm{a}}}\right)\right| \\
(\%)\end{array}$ & $\begin{array}{l}\left|\left(\frac{\mathrm{COP}_{\mathrm{R} 134 \mathrm{a}}-\mathrm{COP}_{\mathrm{LPG}}}{\mathrm{COP}_{\mathrm{R} 134 \mathrm{a}}}\right)\right| \\
(\%)\end{array}$ & $\begin{array}{l}\left|\left(\frac{Q_{R 134 a}-Q_{L P G}}{Q_{R 134 a}}\right)\right| \\
(\%)\end{array}$ & $\begin{array}{l}\left|\left(\frac{I_{\text {tot R134a }}-I_{\text {totLPG }}}{I_{\text {tot R1134a }}}\right)\right| \\
(\%)\end{array}$ & $\begin{array}{l}\left|\left(\frac{\eta_{\mathrm{R} 134 \mathrm{a}}-\eta_{\mathrm{LPG}}}{\eta_{\mathrm{R} 134 \mathrm{a}}}\right)\right| \\
(\%)\end{array}$ \\
\hline 1 & MO & $3.21(-)$ & $24.74(+)$ & $20.74(+)$ & $15.38(-)$ & $31.53(+)$ \\
\hline 2 & $\mathrm{Al}_{2} \mathrm{O}_{3}-\mathrm{MO}$ & $2.69(-)$ & $4.21(+)$ & $1.41(+)$ & $19.62(-)$ & $43.57(+)$ \\
\hline 3 & $\mathrm{TiO}_{2}-\mathrm{MO}$ & $15.87(-)$ & $56.32(+)$ & $31.52(+)$ & $31.69(-)$ & $47.06(+)$ \\
\hline 4 & $\mathrm{SiO}_{2}-\mathrm{MO}$ & $14.11(-)$ & $55.79(+)$ & $33.81(+)$ & $28.94(-)$ & $43.26(+)$ \\
\hline
\end{tabular}

(-) Performance parameters lower than R134a.

(+) Performance parameters higher than R134a.

(a)

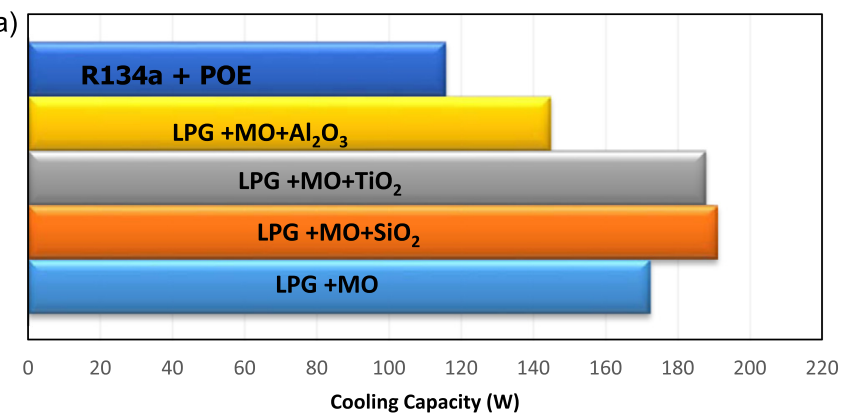

(b)

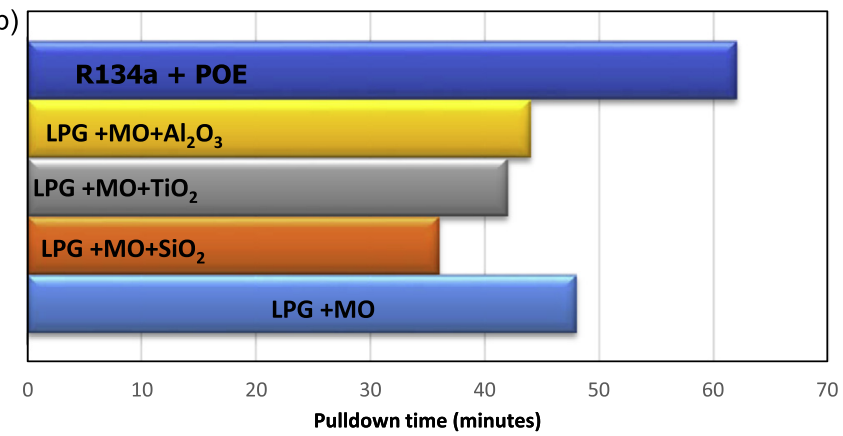

Fig. 8. (a) Comparison of cooling capacity between R134a/POE lubricant and LPG refrigerants with the selected lubricants ( $\mathrm{POE}, \mathrm{MO}, \mathrm{Al}_{2} \mathrm{O}_{3}-\mathrm{MO}, \mathrm{TiO}_{2}-\mathrm{MO}$ and $\mathrm{SiO}_{2}-$ $\mathrm{MO}$ at $0.2 \mathrm{~g} / \mathrm{L}$ concentration of nanoparticle) (8). (b) Comparison of pulldown time of R134a/POE lubricant and LPG refrigerants with the selected lubricants (POE, MO, $\mathrm{Al}_{2} \mathrm{O}_{3}-\mathrm{MO}, \mathrm{TiO}_{2}-\mathrm{MO}$ and $\mathrm{SiO}_{2}-\mathrm{MO}$ at $0.2 \mathrm{~g} / \mathrm{L}$ concentration of nanoparticle).

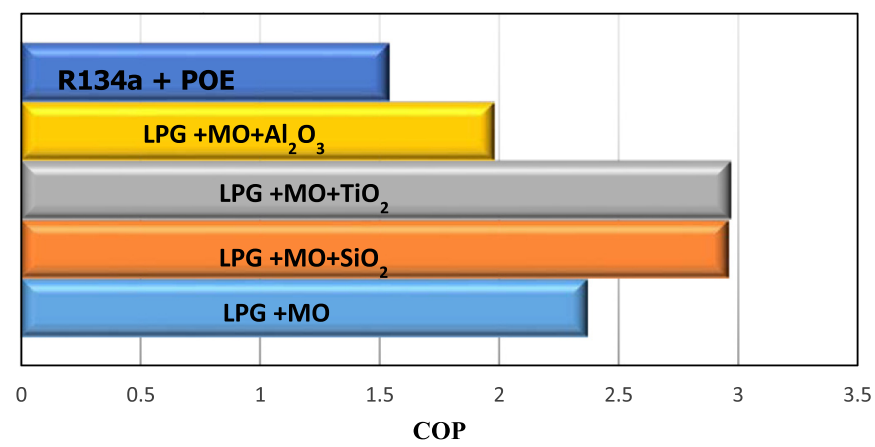

Fig. 9. Comparison of COP between R134a/POE lubricant and LPG refrigerant with the selected lubricants (POE, $\mathrm{MO}, \mathrm{Al}_{2} \mathrm{O}_{3}-\mathrm{MO}, \mathrm{TiO}_{2}-\mathrm{MO}$ and $\mathrm{SiO}_{2}-\mathrm{MO}$ at $0.2 \mathrm{~g} / \mathrm{L}$ concentration of nanoparticle).

Fig. 8(b) shows the behavior of the pulldown time of the mass charge of $100 \mathrm{~g}$ of R134a using POE lubricant and $40 \mathrm{~g}$ of LPG refrigerant using lubricants $\left(\mathrm{MO}, \mathrm{Al}_{2} \mathrm{O}_{3}-\mathrm{MO}, \mathrm{TiO}_{2}-\mathrm{MO}\right.$ and $\mathrm{SiO}_{2}-\mathrm{MO}$ with $0.2 \mathrm{~g} / \mathrm{L}$ nanoparticles). Fig. 8 (b) shows that the pulldown time of the LPG refrigerant using MO lubricant, found to be lower compared to R134a / POE due to the higher latent heat of evaporation according to Gill and Singh (2017d). However, the pulldown time of

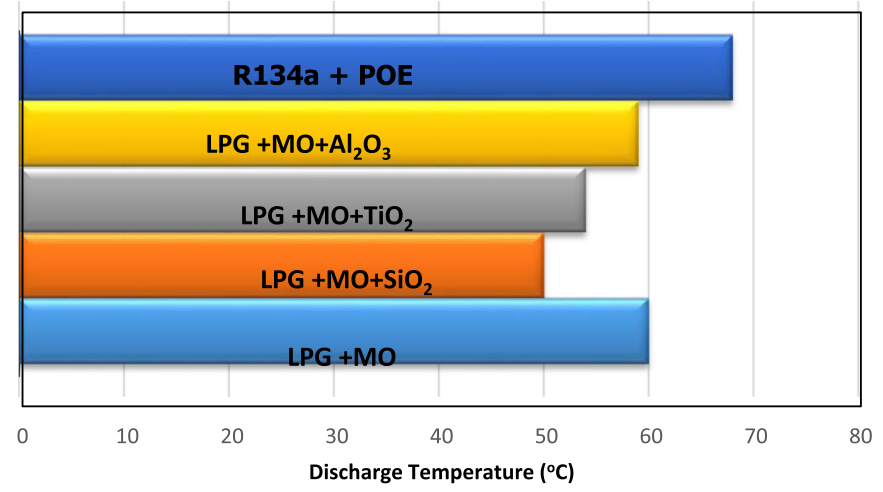

Fig. 10. Comparison of compressor discharge temperature between $\mathrm{R} 134 \mathrm{a} / \mathrm{POE}$ lubricant and LPG refrigerants with the selected lubricants (POE, $\mathrm{MO}, \mathrm{Al}_{2} \mathrm{O}_{3}-\mathrm{MO}, \mathrm{TiO}_{2}$ $\mathrm{MO}$ and $\mathrm{SiO}_{2}-\mathrm{MO}$ at $0.2 \mathrm{~g} / \mathrm{L}$ concentration of nanoparticles).

the LPG refrigerant using nanolubricants $\left(\mathrm{Al}_{2} \mathrm{O}_{3}-\mathrm{MO}, \mathrm{TiO}_{2}-\mathrm{MO}\right.$, and $\mathrm{SiO}_{2}-\mathrm{MO}$ ) found less than the LPG refrigerant using MO lubricant at about $8.3-25.0 \%$; since the critical heat flux is enhanced when the nanofluid is used as a refrigerant than the pure base fluid according to Ohunakin et al. (2017).

The variation in the COP of the domestic refrigerator between R134a/POE lubricant and $40 \mathrm{~g}$ charge of LPG refrigerant infused with different lubricants $\left(\mathrm{MO}, \mathrm{Al}_{2} \mathrm{O}_{3}-\mathrm{MO}, \mathrm{TiO}_{2}-\mathrm{MO}\right.$, and $\mathrm{SiO}_{2}-\mathrm{MO}$ at $0.2 \mathrm{~g} / \mathrm{L}$ concentration of nanoparticles) is shown in Fig. 9. Findings showed that the LPG refrigerant at $40 \mathrm{~g}$ charge with $\mathrm{TiO}_{2}-\mathrm{MO}$ lubricant $\left(0.2 \mathrm{~g} / \mathrm{L}\right.$ of $\left.\mathrm{TiO}_{2}\right)$ had the highest COP on the refrigerator system; this may be due to the fact that LPG with $\mathrm{TiO}_{2}-\mathrm{MO}$ lubricant, gave the least compressor power consumption. Furthermore, it can also be observed from Table 8 that the COP of the test rig using LPG refrigerant at $40 \mathrm{~g}$ charge with $\mathrm{TiO}_{2}$-MO lubricant $(0.2 \mathrm{~g} / \mathrm{L}$ of $\mathrm{TiO}_{2}$ ) was $31.52 \%$ higher than $100 \mathrm{~g}$ charge of $\mathrm{R} 134 \mathrm{a} / \mathrm{POE}$ lubricant. Hence, LPG at $40 \mathrm{~g}$ charge with $\mathrm{TiO}_{2}$-MO lubricant mixture was selected as the best among the LPG/nano-lubricant mixtures capable of replacing $100 \mathrm{~g}$ charge of $\mathrm{R} 134 \mathrm{a} / \mathrm{POE}$ in term of energetic performance. This mixture can also be referred to as the optimum blend according to the work of Poggi et al. (2008).

Fig. 10 depicts the compressor discharge temperature of the domestic refrigerator using R134a (100g: POE) and LPG refrigerants with selected lubricants $\left(40 \mathrm{~g}\right.$ : $\mathrm{MO}, \mathrm{Al}_{2} \mathrm{O}_{3}-\mathrm{MO}, \mathrm{TiO}_{2}-\mathrm{MO}$, and $\mathrm{SiO}_{2}-\mathrm{MO}$ at $0.2 \mathrm{~g} / \mathrm{L}$ of nano-concentration). It was observed that lower discharge pressure was obtained with LPG refrigerant when compared with R134a refrigerant. On the other hand, the addition of nanoparticle further reduced the compression ratio and compressor discharge temperature (see Kumar and Elansezhian, 2014). The compressor discharge temperature of the domestic refrigerator using LPG with the selected lubricants gave lower values than R134/POE lubricant, as shown in Fig. 10. It can also be observed from Table 8 that the compressor discharge temperature of the domestic refrigerator using $40 \mathrm{~g}$ charge of LPG refrigerant with $\mathrm{TiO}_{2}$ MO lubricant $(0.2 \mathrm{~g} / \mathrm{L}$ of concentration), gave lower values of compressor discharge temperature, than R134a/POE lubricant. About 


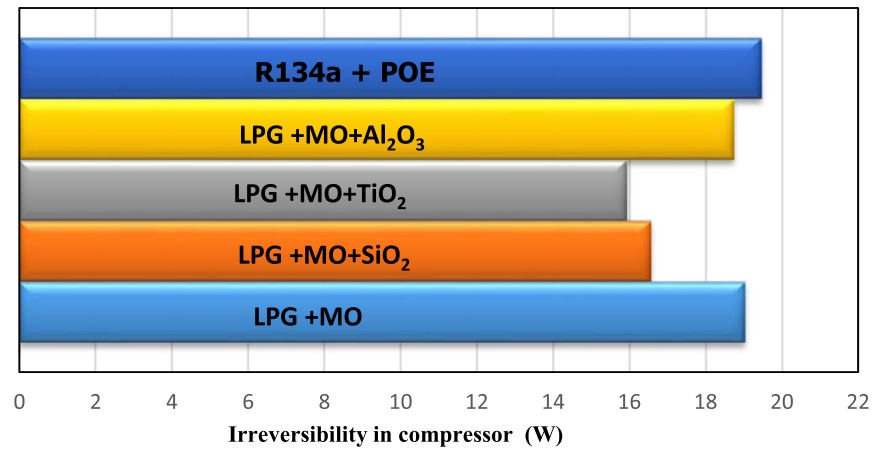

Fig. 11. Comparison of compressor irreversibility with R134a/POE and LPG with the various lubricants (POE, MO, and nano-based at $0.2 \mathrm{~g} / \mathrm{L}$ concentration of nanoparticle).

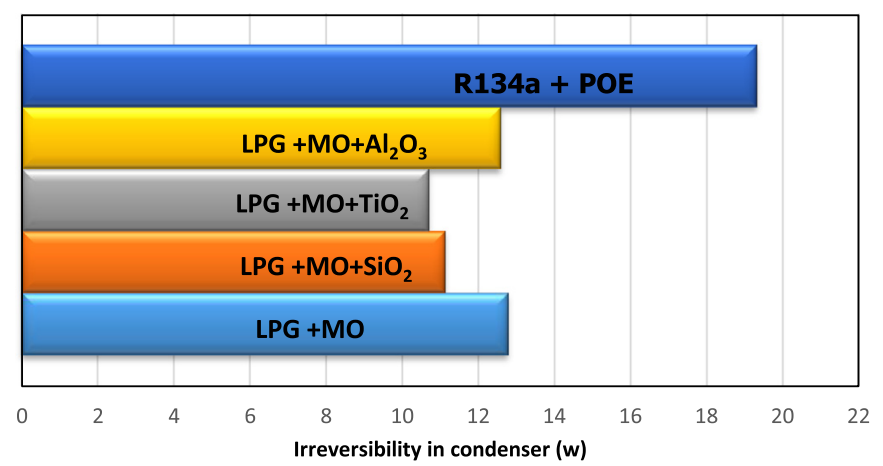

Fig. 12. Comparison of the irreversibility in the condenser between $\mathrm{R} 134 \mathrm{a} / \mathrm{POE}$ and LPG with the selected lubricants (POE, MO, $\mathrm{Al}_{2} \mathrm{O}_{3}-\mathrm{MO}, \mathrm{TiO}_{2}-\mathrm{MO}$ and $\mathrm{SiO}_{2}-\mathrm{MO}$ at $0.2 \mathrm{~g} / \mathrm{L}$ concentration of nanoparticle).

$14{ }^{\circ} \mathrm{C}$ reduction was recorded during investigation; hence, extended compressor life may be expected with the $40 \mathrm{~g}$ charge of $\mathrm{LPG} / \mathrm{TiO}_{2}-$ MO lubricant $(0.2 \mathrm{~g} / \mathrm{L}$ of concentration).

\subsection{Parameters of exergetic performance analysis of domestic refrigerator}

The irreversibility in the compressor of domestic refrigerator working with $100 \mathrm{~g}$ charge of R134a/POE lubricant, and $40 \mathrm{~g}$ charge of LPG refrigerants with the selected lubricants ( $\mathrm{MO}, \mathrm{Al}_{2} \mathrm{O}_{3}-\mathrm{MO}$, $\mathrm{TiO}_{2}-\mathrm{MO}$, and $\mathrm{SiO}_{2}-\mathrm{MO}$ at $0.2 \mathrm{~g} / \mathrm{L}$ of nanoparticle) is depicted in Fig. 11. The irreversibility in the compressor by utilizing LPG with the lubricants $\left(\mathrm{MO}, \mathrm{Al}_{2} \mathrm{O}_{3}-\mathrm{MO}, \mathrm{TiO}_{2}-\mathrm{MO}\right.$ and $\mathrm{SiO}_{2}-\mathrm{MO}$ at $0.2 \mathrm{~g} / \mathrm{L}$ of nanoparticles) resulted in lower values than R134a/POE lubricant, because of the lower pressure ratio and compressor power consumption associated with LPG when compared with R134a refrigerant. This reduction in values is between 2.21 and $18.15 \%$. The lowest value of compressor power consumption of the domestic refrigerator was found using the $40 \mathrm{~g}$ charge of LPG refrigerant with $\mathrm{TiO}_{2}$-MO lubricating oil (see Fig. 7). It should also be noted that the least compressor irreversibility value was given by $\mathrm{LPG} / \mathrm{TiO}_{2}-\mathrm{MO}$ lubricating oil, because the mixture resulted in the minimum compressor power consumption. The value of the irreversibility in the compressor for the $40 \mathrm{~g}$ charge of LPG refrigerant with $\mathrm{TiO}_{2}-\mathrm{MO}$ lubricant $(0.2 \mathrm{~g} / \mathrm{L}$ of nano concentration), was found to be $18.15 \%$ lower than the $100 \mathrm{~g}$ charge of R134a infused with POE lubricant.

Fig. 12 depicts the irreversibility in the condenser of domestic refrigerator with $100 \mathrm{~g}$ charge of $\mathrm{R} 134 \mathrm{a} / \mathrm{POE}$ lubricant and $40 \mathrm{~g}$ charge of LPG refrigerants with the selected lubricants ( $\mathrm{MO}, \mathrm{Al}_{2} \mathrm{O}_{3}$ $\mathrm{MO}, \mathrm{TiO}_{2}-\mathrm{MO}$ and $\mathrm{SiO}_{2}-\mathrm{MO}$ at $0.2 \mathrm{~g} / \mathrm{L}$ of the nanoparticle). The heat transfer coefficients and thermal conductivity of hydrocarbon blends were found to be superior to R134a in the work of

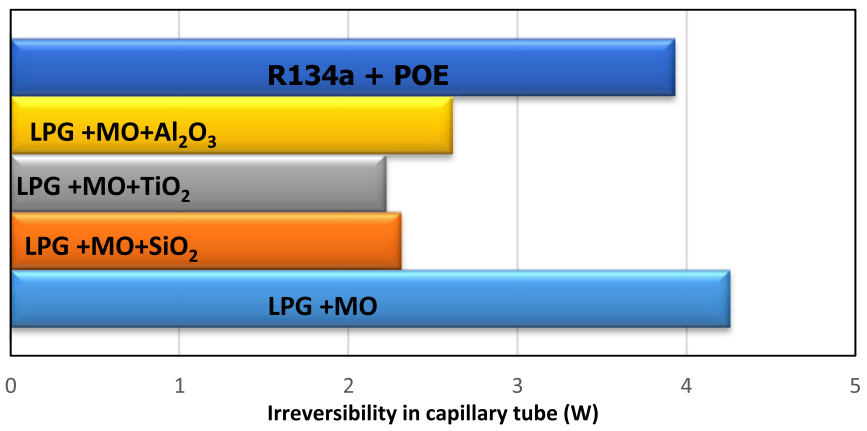

Fig. 13. Comparison of the irreversibility in a capillary tube for R134a and LPG refrigerants with the various lubricants ( $\mathrm{POE}, \mathrm{MO}, \mathrm{Al}_{2} \mathrm{O}_{3}-\mathrm{MO}, \mathrm{TiO}_{2}-\mathrm{MO}$ and $\mathrm{SiO}_{2}-\mathrm{MO}$ at $0.2 \mathrm{~g} / \mathrm{L}$ concentration of nanoparticles).

Adelekan et al. (2017). In the work of Ohunakin et al. (2017), the heat transfer capability of nanofluids (base liquids that homogenized with nanoparticles) was found to be greatly enhanced than that of pure base fluids. Hence, irreversibility in the condenser utilizing LPG refrigerant with the selected lubricants gave a reduction between $33.84 \%$ and $44.63 \%$ when compared with $\mathrm{R} 134 \mathrm{a} / \mathrm{POE}$ lubricant. This is due to the inherent higher thermal conductivity and heat transfer coefficients. Enhancement in thermal conductivity values of around $0.45-2.75 \%$ were observed by utilizing $\mathrm{SiO}_{2}$ and $\mathrm{TiO}_{2}$ nano-lubricants when compared with the base liquid (LPG), at the discharge line of the compressor; $\mathrm{Al}_{2} \mathrm{O}_{3}$ nanolubricant had no effect on thermal conductivity with the base liquid (LPG) (see Ohunakin et al., 2017). From the condenser, more heat is exchanged to the atmosphere with $\mathrm{TiO}_{2}-\mathrm{MO}$. Hence, the least irreversibility in condenser was found with $40 \mathrm{~g}$ charge of LPG using $\mathrm{TiO}_{2}$-MO lubricant $\left(0.2 \mathrm{~g} / \mathrm{L}\right.$ of $\left.\mathrm{TiO}_{2}\right)$. It was further observed that irreversibility in the condenser for the LPG at $40 \mathrm{~g}$ charge using $\mathrm{TiO}_{2}$-MO lubricant $(0.2 \mathrm{~g} / \mathrm{L}$ nano-concentration), gave a $44.63 \%$ reduction than that obtained with $\mathrm{R} 134 \mathrm{a}$ at $100 \mathrm{~g}$ charge using POE lubricant.

Fig. 13 illustrates the irreversibility in the capillary tube of the domestic refrigerator working with $100 \mathrm{~g}$ charge of R134a (POE lubricant) and $40 \mathrm{~g}$ charge of LPG refrigerants with the selected lubricants $\left(\mathrm{MO}, \mathrm{Al}_{2} \mathrm{O}_{3}-\mathrm{MO}, \mathrm{TiO}_{2}-\mathrm{MO}\right.$, and $\mathrm{SiO}_{2}-\mathrm{MO}$ at $0.2 \mathrm{~g} / \mathrm{L}$ of the selected nanoparticles). The irreversibility in the capillary tube of a refrigeration system utilizing hydrocarbon blends i.e. LPG (40 g charge: MO lubricant), was found to be higher than that of R134a (100g charge: POE lubricant). This assertion was also confirmed in the work of Padmanabhan and Palanisamy (2012). Hence, hydrocarbon blends are found to encounter critical throttle losses when compared with R134a. It was found in the work of Fatouh and Kafafy (2006), that a reduction of mass flow rate in the capillary tube using LPG ( $40 \mathrm{~g}$ charge: MO lubricant), can be obtained by increasing capillary tube length at constant internal diameter. Under this condition, the entropy generation or irreversibility in the capillary will reduce as per Gill and Singh (2018b). Furthermore, the addition of nanoparticles to the base working fluid (LPG) has made the working fluid (nanofluid) to increase in density and viscosity, thereby compensating for the additional pressure drop (see $\mathrm{Li}$ and Kleinstreuer, 2008). Hence, the irreversibility in the capillary tube for LPG at $40 \mathrm{~g}$ charge with the selected lubricants $\left(\mathrm{Al}_{2} \mathrm{O}_{3}-\mathrm{MO}\right.$, $\mathrm{TiO}_{2}-\mathrm{MO}, \mathrm{SiO}_{2}-\mathrm{MO}$ lubricants at $0.2 \mathrm{~g} / \mathrm{L}$ concentration of nanoparticles), was thus found to be lower than that of R134a (100 g charge: POE lubricant) by about $33.60-43.43 \%$. At the discharge side of the compressor (of the domestic refrigerator), both $\mathrm{SiO}_{2}$ and $\mathrm{TiO}_{2}$ nano-lubricant had about 0.99 and $6.09 \%$ increment in viscosity, respectively, while for both LPG-MO and LPG- $\mathrm{Al}_{2} \mathrm{O}_{3}$, viscosity values are the same at $103.97 \mathrm{mPa}$ s (see Ohunakin et al., 2017). Due to the high viscosity, substantial pressure drops happened in the 


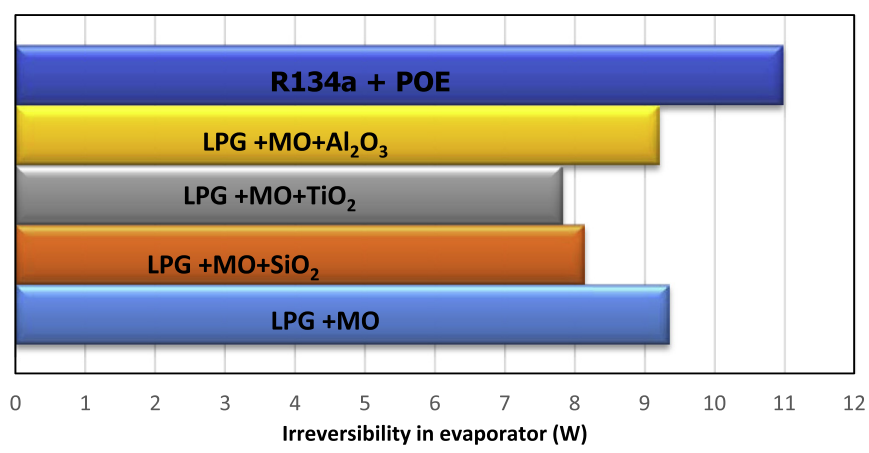

Fig. 14. Comparison of the irreversibility in the evaporator for R134a and LPG refrigerants with the various lubricants ( $\mathrm{POE}, \mathrm{MO}, \mathrm{Al}_{2} \mathrm{O}_{3}-\mathrm{MO}, \mathrm{TiO}_{2}-\mathrm{MO}$ and $\mathrm{SiO}_{2}-\mathrm{MO}$ at $0.2 \mathrm{~g} / \mathrm{L}$ concentration of nanoparticle).

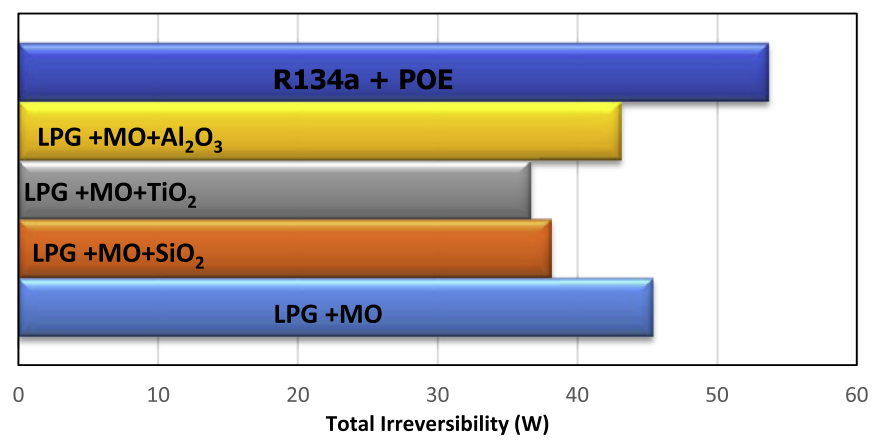

Fig. 15. Comparison of the total irreversibility for R134a and LPG refrigerants with the various lubricants (POE, $\mathrm{MO}, \mathrm{Al}_{2} \mathrm{O}_{3}-\mathrm{MO}, \mathrm{TiO}_{2}-\mathrm{MO}$ and $\mathrm{SiO}_{2}-\mathrm{MO}$ at $0.2 \mathrm{~g} / \mathrm{L}$ concentration of nanoparticle).

capillary tube, and subsequently resulted in the least irreversibility obtained in the capillary tube for the $40 \mathrm{~g}$ charge of LPG based $\mathrm{TiO}_{2}$-MO lubricant $\left(0.2 \mathrm{~g} / \mathrm{L}\right.$ of $\mathrm{TiO}_{2}$ concentration). In addition, it was found that irreversibility in a capillary tube for the $40 \mathrm{~g}$ charge of LPG based $\mathrm{TiO}_{2}$-MO lubricant, was $43.43 \%$ lower than that of the $100 \mathrm{~g}$ charge of R134a refrigerant with POE lubricant.

Fig. 14 depicts the irreversibility in the evaporator of the domestic refrigerator with R134a at $100 \mathrm{~g}$ charge using POE lubricant, and $40 \mathrm{~g}$ charge of LPG refrigerants with the selected lubricants ( $\mathrm{MO}, \mathrm{Al}_{2} \mathrm{O}_{3}-\mathrm{MO}, \mathrm{TiO}_{2}-\mathrm{MO}$ and $\mathrm{SiO}_{2}-\mathrm{MO}$ at $0.2 \mathrm{~g} / \mathrm{L}$ concentration of the respective nanoparticles). Thermal conductivity of LPG refrigerant was found to be higher than that of R134a refrigerant. Furthermore, heat exchange capability of nanofluids was found to be better enhanced than that of the pure base refrigerant (Ohunakin et al., 2017). It was also observed that the irreversibility in the evaporator utilizing LPG refrigerant with the selected lubricants (MO, $\mathrm{Al}_{2} \mathrm{O}_{3}-\mathrm{MO}, \mathrm{TiO}_{2}-\mathrm{MO}$ and $\mathrm{SiO}_{2}-\mathrm{MO}$ at $0.2 \mathrm{~g} / \mathrm{L}$ concentration of the respective nanoparticles) was lower than that of the $100 \mathrm{~g}$ charge of R134a refrigerant with POE lubricant, by about $14.80-28.69 \%$. In addition, it was discovered that LPG at $40 \mathrm{~g}$ charge using $\mathrm{TiO}_{2}-\mathrm{MO}$ lubricant $\left(0.2 \mathrm{~g} / \mathrm{L}\right.$ concentration of $\left.\mathrm{TiO}_{2}\right)$, exchanged more amount of heat during evaporation process at higher temperature and pressure. LPG refrigerant at $40 \mathrm{~g}$ charge with $\mathrm{TiO}_{2}-\mathrm{MO}$ lubricant $(0.2 \mathrm{~g} / \mathrm{L}$ concentration of $\mathrm{TiO}_{2}$ ) was thus discovered to give the lowest irreversibility in the evaporator, and found to be $28.69 \%$ lower than that of R134a at $100 \mathrm{~g}$ charge with POE lubricant.

Figs. 15 and 16 show the variations in the total irreversibility and second law efficiency of the domestic refrigerator, with $100 \mathrm{~g}$ charge of R134a/POE lubricant and LPG refrigerants at $40 \mathrm{~g}$ charge with the selected lubricants $\left(\mathrm{MO}, \mathrm{Al}_{2} \mathrm{O}_{3}-\mathrm{MO}, \mathrm{TiO}_{2}-\mathrm{MO}\right.$ and $\mathrm{SiO}_{2}-\mathrm{MO}$ at $0.2 \mathrm{~g} / \mathrm{L}$ of the respective nanoparticles). Figs. 11 and 14 showed that the irreversibility in the most of sub-components of the domestic refrigerator using LPG refrigerant with selected lu-

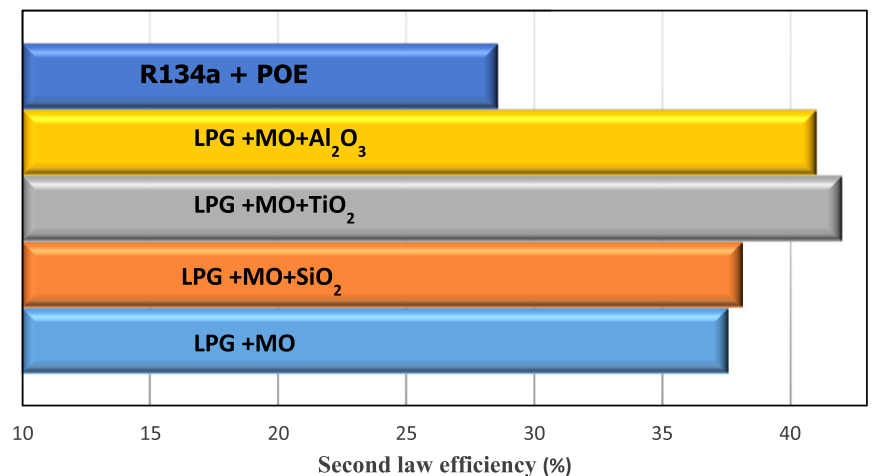

Fig. 16. Comparison of second law efficiency for R134a and LPG refrigerants with the various lubricants (POE, $\mathrm{MO}, \mathrm{Al}_{2} \mathrm{O}_{3}-\mathrm{MO}, \mathrm{TiO}_{2}-\mathrm{MO}$ and $\mathrm{SiO}_{2}-\mathrm{MO}$ at $0.2 \mathrm{~g} / \mathrm{L}$ concentration of nanoparticle).

bricants was lower than R134a/POE lubricant. Along these lines, total irreversibility of LPG refrigerant with the selected lubricants gave a reduction of between $15.38-31.69 \%$, than that of $\mathrm{R} 134 \mathrm{a} / \mathrm{POE}$ lubricant. A reduction in compressor power was also observed using LPG refrigerant with the selected lubricants $\left(\mathrm{MO}, \mathrm{Al}_{2} \mathrm{O}_{3}-\mathrm{MO}\right.$, $\mathrm{TiO}_{2}-\mathrm{MO}$, and $\mathrm{SiO}_{2}-\mathrm{MO}$ at $0.2 \mathrm{~g} / \mathrm{L}$ of the respective nanoparticles) than the R134a-POE lubricant see Fig. 7. Thus, the second law efficiency values of LPG refrigerant/lubricants blends (i.e. $\mathrm{MO}, \mathrm{Al}_{2} \mathrm{O}_{3}$ $\mathrm{MO}, \mathrm{TiO}_{2}-\mathrm{MO}$, and $\mathrm{SiO}_{2}-\mathrm{MO}$ at $0.2 \mathrm{~g} / \mathrm{L}$ of the respective nanoparticles) increased by $31.53-47.06 \%$ than the $\mathrm{R} 134 \mathrm{a} / \mathrm{POE}$ lubricant baseline by recalling the definition of second law efficiency. In addition, irreversibility in the components and compressor power consumption of domestic refrigerator utilizing LPG with $\mathrm{TiO}_{2}$ MO lubricant were reduced. Hence, total irreversibility and second law efficiency of domestic refrigerator utilizing LPG at $40 \mathrm{~g}$ charge with $\mathrm{TiO}_{2}-\mathrm{MO}$ lubricant $(0.2 \mathrm{~g} / \mathrm{L}$ concentration) improved accordingly (i.e. minimum and maximum values, respectively) (see Table 7). Furthermore, the total irreversibility and second law efficiency of the domestic refrigerator using $40 \mathrm{~g}$ charge of LPG with $\mathrm{TiO}_{2}$-MO lubricant $\left(0.2 \mathrm{~g} / \mathrm{L}\right.$ of $\left.\mathrm{TiO}_{2}\right)$ was adjudged the best; values of about $31.69 \%$ reduction and $47.06 \%$ improvement were obtained for the irreversibility and second law efficiency respectively, in comparison with R134a/POE lubricant at $100 \mathrm{~g}$ charge (Table 8). Therefore, $\mathrm{TiO}_{2}-\mathrm{MO}$ lubricant mixture was selected as the optimal nanoparticle-lubricant mixture in terms of exergetic performance analysis of the working fluids.

\section{Conclusions}

From the study, the following conclusions were drawn:

1. Based on the energetic performance analysis of the domestic refrigerator system, using R134a and LPG refrigerants with the selected lubricants (i.e. $\mathrm{POE}, \mathrm{MO}, \mathrm{TiO}_{2}-\mathrm{MO}, \mathrm{SiO}_{2}-\mathrm{MO}$ and $\mathrm{Al}_{2} \mathrm{O}_{3}-\mathrm{MO}$ with $0.2 \mathrm{~g} / \mathrm{L}$ of the nanoparticle), the COP value of the $40 \mathrm{~g}$ charge of $\mathrm{LPG} / \mathrm{TiO}_{2}-\mathrm{MO}\left(0.2 \mathrm{~g} / \mathrm{L}\right.$ of $\left.\mathrm{TiO}_{2}\right)$ was the highest. An improvement of about $56.32 \%$ was recorded when compared with the $100 \mathrm{~g}$ charge of R134a/POE. In addition, the compressor power consumption of the domestic refrigerator system with the $40 \mathrm{~g}$ charge of $\mathrm{LPG} / \mathrm{TiO}_{2}-\mathrm{MO}\left(0.2 \mathrm{~g} / \mathrm{L}\right.$ of $\left.\mathrm{TiO}_{2}\right)$, gave the least value and found to be $15.87 \%$ lower than R134a (100 g: POE lubricant).

2. The pulldown time and compressor discharge temperature of the system with LPG refrigerants and the selected lubricants $\left(\mathrm{MO}, \mathrm{TiO}_{2}-\mathrm{MO}, \mathrm{SiO}_{2}-\mathrm{MO}\right.$, and $\mathrm{Al}_{2} \mathrm{O}_{3}-\mathrm{MO}$ at $0.2 \mathrm{~g} / \mathrm{L}$ of the nanoparticles) were lower than that of R134a/POE lubricant. It was also found that the pulldown time and compressor discharge temperature with the $40 \mathrm{~g}$ charge of $\mathrm{LPG} / \mathrm{TiO}_{2}-\mathrm{MO}$ 
$\left(0.2 \mathrm{~g} / \mathrm{L}\right.$ of $\left.\mathrm{TiO}_{2}\right)$, were lower than the $100 \mathrm{~g}$ charge of R134a/POE lubricant, by around $20 \mathrm{~min}$ and $14^{\circ} \mathrm{C}$, resapectively.However, the least pull down time and compressor discharge temperature were observed with the $40 \mathrm{~g}$ charge of $\mathrm{LPG} / \mathrm{SiO}_{2}-\mathrm{MO}(0.2 \mathrm{~g} / \mathrm{L}$ of $\mathrm{SiO}_{2}$ ).

3. Exergetic performance analysis of R134a and LPG refrigerants with the selected lubricants (i.e. $\mathrm{POE}, \mathrm{MO}, \mathrm{TiO}_{2}-\mathrm{MO}, \mathrm{SiO}_{2}-$ $\mathrm{MO}$ and $\mathrm{Al}_{2} \mathrm{O}_{3}-\mathrm{MO}$ with $0.2 \mathrm{~g} / \mathrm{L}$ of the nanoparticle), showed that the $40 \mathrm{~g}$ of $\mathrm{LPG} / \mathrm{TiO}_{2}-\mathrm{MO}\left(0.2 \mathrm{~g} / \mathrm{L}\right.$ of $\left.\mathrm{TiO}_{2}\right)$ gave the lowest and highest values of total irreversibility and second law efficiency, respectively, with the domestic refrigerator. The total irreversibility and second law efficiency of the system using LPG (40 g: $\mathrm{TiO}_{2}-\mathrm{MO}$ oil with $0.2 \mathrm{~g} / \mathrm{L}$ of $\mathrm{TiO}_{2}$ ), were respectively found to be lower and higher than that of $100 \mathrm{~g}$ charge of R134a/POE lubricant, by about $31.69 \%$ and $47.06 \%$.

4. In this study, $\mathrm{TiO}_{2}$-MO lubricant mixture was found as the optimal nanoparticle-lubricant mixture among the selected lubricants, in terms of energetic and exergetic performances of the working fluids.

\section{Acknowledgment}

The authors would like to acknowledge the Aman Bhalla Institute of Engineering and Technology, Pathankot;BCET Gurdaspur and Covenant University, Ogun State, Nigeria for their excellent support

\section{Competing interest}

The authors declare no competing financial interest.

\section{References}

Adelekan, D.S., Ohunakin, O.S., Babarinde, T.O., Odunfa, M.K., Leramo, R.O. Oyedepo, S.O., Badejo, D.C, 2017. Experimental performance of LPG refrigerant charges with varied concentration of $\mathrm{TiO} 2$ nano-lubricants in a domestic refrigerator. Case Stud. Therm. Eng. 9, 55-61.

Ahamed, J.U., Saidur, R., Masjuki, H.H, 2010. Thermodynamic performance analysis of R-600 and R-600a as a refrigerant. Eng. E Trans. 5, 11-18.

Ahamed, J., Saidur, R., Masjuki, H, 2011. Prospect of hydrocarbon uses based on exergy analysis in the vapor compression refrigeration system. In: Proceedings of the 2011 IEEE First Conference on Clean Energy and Technology (CET). IEEE, pp. 300-304.

Ahamed, J.U., Saidur, R., Masjuki, H.H., Sattar, M.A, 2012. Energy and thermodynamic performance of LPG as an alternative refrigerant to R-134a in a domestic refrigerator. Energy Sci. Res. 29 (1), 597-610.

Akash, B.A., Said, S.A, 2003. Assessment of LPG as a possible alternative to R-12 in a domestic refrigerator. Energy Convers. Manag. 44, 381-388.

Arora, A., Kaushik, S.C, 2008. Theoretical analysis of a vapor compression refrigeration system with R502, R404A, and R507A. Int. J. Refrigeration 31, 998-1005.

Arun kumar, S.P., Mathews, Prabha, P.K., Performance, C., 2014. Studies on vapour compression refrigeration system. Int. J. Res. Emerg. Sci. Technol. 1 (5), 87-90.

Azmi, W.H., Sharma, K.V., Mamat, R., Najafi, G., Mohamad, M.S., 2016. The enhancement of effective thermal conductivity and effective dynamic viscosity of nanofluids - a review. Renew. Sustain. Energy Rev. 53, 1046-1058.

Azmi, W.H., Sharifa, M.Z., Yusofa, T.M., Mamata, Rizalman, Redhwana, A.A.M, 2017 Potential of nanorefrigerant and nanolubricant on energy saving in refrigeration system - a review. Renew. Sustain. Energy Rev. 69, 415-428.

Babarinde, T.O., Ohunakin, O.S., Adelekan, D.S., Oyedepo, S.O, 2015. Experimental study of LPG And R134a refrigerants in vapor compression refrigeration. Int. Journal of Energy Clean Environ. 16 (1-4), 71-80.

Bejan, A., 2002. Fundamentals of exergy analysis, entropy generation minimization, and the generation of flow architecture. Int. J. Energ. Res. 26, 545-565.

Bi, S., Shi, L., Zhang, Li, 2008. Application of nanoparticles in domestic refrigerators. Appl. Therm. Eng. 28, 1834-1843.

Bi, S., Guo, K., Liu, Z., Wu, J., 2011. Performance of a domestic refrigerator using $\mathrm{TiO}_{2}$-R600a nano-refrigerant as working fluid. Energy Convers. Manage 52, 733-737.

Bobbo, S., Fedele, L., Fabrizio, M., Barison, S., Battiston, S., Pagura, C., 2010. Influence of nanoparticles dispersion in POE oils on lubricity and R134a solubility. Int. J. Refrigeration 33, 1180-1186.

Bolaji, B.O., Isreal, OlatunjiAbiala., Olasunkanmi, Salamilsmaila, Francis, OlusesiBorokinni, 2014. A theoretical comparison of two eco-friendly refrigerants as alternatives to R22 using a simple vapour compression refrigeration system. Trans. FAMENA 38 (3), 59-70.

Botha, S.S, 2007. Sythesis and Characterization of Nanofluids for Cooling Applications. University of the Western Cape, South Africa.
Dincer, I., Rosen, M.A., 2005. Thermodynamic aspects of renewables and sustainable development. Renew. Sust. Energ. Rev. 9, 169-189.

Fang, G., Xing, L., Yang, F., Li, H, 2005. Exergy analysis of a dual mode refrigeration system for ice storage air conditioning. Int. J. Archit. Sci. 6, 1-6.

Fatouh, M, Kafafy, M, 2006. E. Experimental evaluation of a domestic refrigerator working with LPG. Appl. Therm. Eng. 26, 1593-1603.

Gill, J., Singh, J., 2017a. Energetic and Exergetic performance analysis of the vapor compression refrigeration system using adaptive neuro-fuzzy inference system approach. Exp. Therm. Fluid Sci. 88, 246-260.

Gill, J., Singh, J., 2017b. Adaptive neuro-fuzzy inference system approach to predict the mass flow rate of R134a/LPG refrigerant for straight and helical coiled adiabatic capillary tubes in the vapor compression refrigeration system. Int. J. Refrigeration $78,166-175$

Gill, J., Singh, J., 2017c. Performance analysis of vapor compression refrigeration system using an adaptive neuro-fuzzy inference system. Int. J. Refrigeration 82, 436-446.

Gill, J., Singh, J., 2017d. Energy analysis of vapor compression refrigeration system using mixture of R134a and LPG as refrigerant. Int. J. Refrigeration 84, 287299.

Gill, J., Singh, J., 2017e. Experimental Analysis of R134a/LPG as replacement of R134a in a vapor-compression refrigeration system. Int. J. Air-Condition. Refrigeration, 1750015.

Gill, J, Singh, J, 2018b. Component-Wise Energy analysis of Vapor Compression Refrigeration system using mixture of R134a and LPG as refrigerant. Heat Mass Transf. 1-14.

Gill, J., Singh, J., Ohunakin, O.S., Adelekan, D.S., 2018. Artificial neural network approach for irreversibility performance analysis of domestic refrigerator by utilizing LPG with $\mathrm{TiO}_{2}$-lubricant as replacement of R134a. Int. J. Refrigeration 89 (2018), 159-176.

Golzari, S., Kasaeian, A., Daviran, S., Mahian, O., Wongwises, S., Sahin, A.Z, 2017. Second law analysis of an automotive air conditioning system using HFO-1234yf, an environmentally friendly refrigerant. Int. J. Refrigeration 73, 134-143.

Hepbasli, A, 2007. Thermoeconomic analysis of household refrigerators. Int. J. Energ. Res 31, 947-959.

Jwo, C.S., Jeng, L.Y., Teng, T.P., Chang, H., 2009. Effects of nanolubricant on performance of hydrocarbon refrigerant system. J. Vac. Sci. Technol. B 27 (3), 1473-1477.

Kabul, A., Kizilkan, O., Yakut, A.K., 2008. Performance and Energetic analysis of vapor compression refrigeration system with an internal heat exchanger using a hydrocarbon, isobutane (R600a). Int. J. Energ. Res. 32, 824-836.

Kumar, D.S., Elansezhian, R.D., 2012. Experimental study on Al203-R134a nanorefrigerant in refrigeration system. Int. J. Mod. Eng. Res. 2 (5), 3927-3929.

Kumar, D.S., Elansezhian, R., 2014. ZnO nanorefrigerant in R152a refrigeration system for energy conservation and green environment. Front. Mech. Eng. 9, 75-80.

$\mathrm{Li}$, J., Kleinstreuer, C., 2008. Thermal performance of nanofluid flow in microchannels. Int. J. Heat Fluid Flow 29, 1221-1232.

Lou, J.F., Zhang, H., Wang, R., 2015. Experimental investigation of graphite nanolubricant used in a domestic refrigerator. Adv. Mech. Eng. 7 [1687814015571011].

Mohanraj, M, Muraleedharan, C, Jayaraj, S, 2011. A. Review of recent developments in new refrigerant mixtures for vapor compression based refrigeration, air conditioning and heat pump units. Int. J. Energy Res. 35 (8), 647-669.

Ohunakin, O.S., Adelekan, D.S., Babarinde, T.O., Leramo, R.O., Abam, F. ., Diarra, C.D. 2017. Experimental investigation of $\mathrm{TiO}_{2}-, \mathrm{SiO}_{2}$-and $\mathrm{Al}_{2} \mathrm{O}_{3}$-lubricants for a domestic refrigerator system using LPG as working fluid. Appl. Therm. Eng. 127, 1469-1477.

Padmanabhan, V.M.V., Palanisamy, S., 2012. The use of TiO2 nanoparticles to reduce refrigerator IR-reversibility. Energy Convers. Manag. 59, 122-132.

Poggi, F., Macchi-Tejeda, H., Leducq, D., Bontemps, A., 2008. Refrigerant charge in refrigerating systems and strategies of charge reduction. Int. J. Refrigeration 31 (3), 353-370.

Raveendran, P.S., Sekhar, S.J, 2017. Exergy analysis of a domestic refrigerator with brazed plate heat exchanger as a condenser. J. Therm. Anal. Calorim. 1-8.

Rosen, M.A., Dincer, I., Kanoglu, M., 2008. Role of Exergy in increasing efficiency and sustainability and reducing environmental impact. Energy Policy 36, 128137.

Sabareesh, R.K., Gobinath, N., Sajith, V., Das, S., Sobhan, C.B., 2012. Application of $\mathrm{TiO}_{2}$ nanoparticles as a lubricant-additive for vapor compression refrigeration systems-an experimental investigation. Int. J. Refrig. 35, 19891996.

Sanchez, D., Cabello, R., Llopis, R., Arauzo, I., Catalán-Gil, J., Torrella, E., 2017. Energy performance evaluation of R1234yf, R1234ze (E), R600a, R290 and R152a as low-GWP a alternatives. Int. J. Refrigeration 74, 267-280.

Saravanakumar, R., Selladurai, V, 2014. Exergy analysis of a domestic refrigerator using eco-friendly R290/R600a refrigerant mixture as an alternative to R134a. J. Ther. Anal. Calorim. 115 (1), 933-940.

Schultz, R., Cole, R., 1979. Uncertainty analysis in boiling nucleation. In: Proceedings of the AICHE Symposium Series.

Sendil Kumar, D., Elansezhain, R., 2012. Experimental study of $\mathrm{Al}_{2} \mathrm{O}_{3}-\mathrm{R} 134 \mathrm{a}$ nano-refrigerant in refrigeration system. Int. J. Modern Eng. Res. 2 (5) 3927-3929.

Sheikholeslami, M., Ganji, D.D., 2016. Heat transfer enhancement in an air to water heat exchanger with discontinuous helical turbulators; experimental and numerical studies. Energy 116, 341-352.

Srinivas, P., Chandra, R.P., Kumar, M.R., Reddy, N., 2014. Experimental investigation of LPG as refrigerant in a domestic refrigerator. J. Mech. Eng. Res. Technol. 2 (1), 470-476. 
Subramani, N., Prakash, M.J., 2011. Experimental studies on a vapour compression system using nanorefrigerants. Int. J. Eng. Sci. Technol. 3 (9), 95-102.

Sundar, L.S., Sharma, K.V., Naik, M.T., Singh, M.K., 2013. Empirical and theoretical correlations on viscosity of nanofluids: a review. Renew. Sust. Energ. Rev. 25, 670-686.
Wang, R.X., Hao, B., Xie, G.Z., Li, H.Q., 2003. A refrigerating system using HFC134a and mineral lubricant appended with $\mathrm{n}-\mathrm{TiO}_{2}$ (R) as working fluids. In: Proceedings of the Forth International Symposium on HAVC. Beijing, China. Tsinghua University Press, pp. 888-892.

Yu, W., Xie, H., 2012. A review on nanofluids: preparation, stability mechanisms, and applications. J. Nanomater 1-17. 